OPEN ACCESS

Edited by:

Junpei Zhou,

Yunnan Normal University, China

Reviewed by:

Hongge Chen,

Henan Agricultural University, China

Ramón Alberto Batista-García,

Universidad Autónoma del Estado

de Morelos, Mexico

*Correspondence:

Tulasi Satyanarayana

tsnarayana@gmail.com

Specialty section:

This article was submitted to

Extreme Microbiology,

a section of the journal

Frontiers in Microbiology

Received: 11 April 2020

Accepted: 21 August 2020

Published: 17 September 2020

Citation:

Verma $D$ and Satyanarayana $T$ (2020) Xylanolytic Extremozymes

Retrieved From Environmental

Metagenomes: Characteristics,

Genetic Engineering,

and Applications.

Front. Microbiol. 11:551109.

doi: 10.3389/fmicb.2020.551109

\section{Xylanolytic Extremozymes Retrieved From Environmental Metagenomes: Characteristics, Genetic Engineering, and Applications}

\author{
Digvijay Verma $^{1}$ and Tulasi Satyanarayana ${ }^{2 *}$
}

1 Department of Microbiology, Babasaheb Bhimrao Ambedkar (Central) University, Lucknow, India, ${ }^{2}$ Department of Biological Sciences and Engineering, Netaji Subhas University of Technology, Dwarka, New Delhi, India

Xylanolytic enzymes have extensive applications in paper, food, and feed, pharmaceutical, and biofuel industries. These industries demand xylanases that are functional under extreme conditions, such as high temperature, acidic/alkaline $\mathrm{pH}$, and others, which are prevailing in bioprocessing industries. Despite the availability of several xylan-hydrolyzing enzymes from cultured microbes, there is a huge gap between what is available and what industries require. DNA manipulations as well as protein-engineering techniques are also not quite satisfactory in generating xylanhydrolyzing extremozymes. With a compound annual growth rate of $6.6 \%$ of xylanhydrolyzing enzymes in the global market, there is a need for xylanolytic extremozymes. Therefore, metagenomic approaches have been employed to uncover hidden xylanolytic genes that were earlier inaccessible in culture-dependent approaches. Appreciable success has been achieved in retrieving several unusual xylanolytic enzymes with novel and desirable characteristics from different extreme environments using functional and sequence-based metagenomic approaches. Moreover, the Carbohydrate Active Enzymes database includes approximately $400 \mathrm{GH}-10$ and $\mathrm{GH}-11$ unclassified xylanases. This review discusses sources, characteristics, and applications of xylanolytic enzymes obtained through metagenomic approaches and their amelioration by genetic engineering techniques.

Keywords: extremozymes, xylanolytic enzymes, metagenomes, metagenomics, GH-10 and GH-11 xylanases, genetic engineering

\section{INTRODUCTION}

Extensive biotechnological applications of xylanolytic extremozymes have raised interest as well as their demand in several industrial processes. Extremozymes are expected to withstand extreme conditions posed during the downstream processing of lignocellulosic materials. For example, thermo-alkali-stable xylanases are well suited for the paper industry for their use in bio-bleaching of paper pulp (Kumar et al., 2016; Figure 1). The bread industry prefers xylanases/ $\beta$-xylosidases of thermo-acid stable properties (Uhl and Daniel, 1999; Harris and Ramalingam, 2010; Kumar et al., 2016). Salt-tolerant hemicellulases are the choice of seafood processing industries (Al-Darkazali et al., 2017). Similarly, barophilic, psychrophilic, and xylan-degrading enzymes functional at 

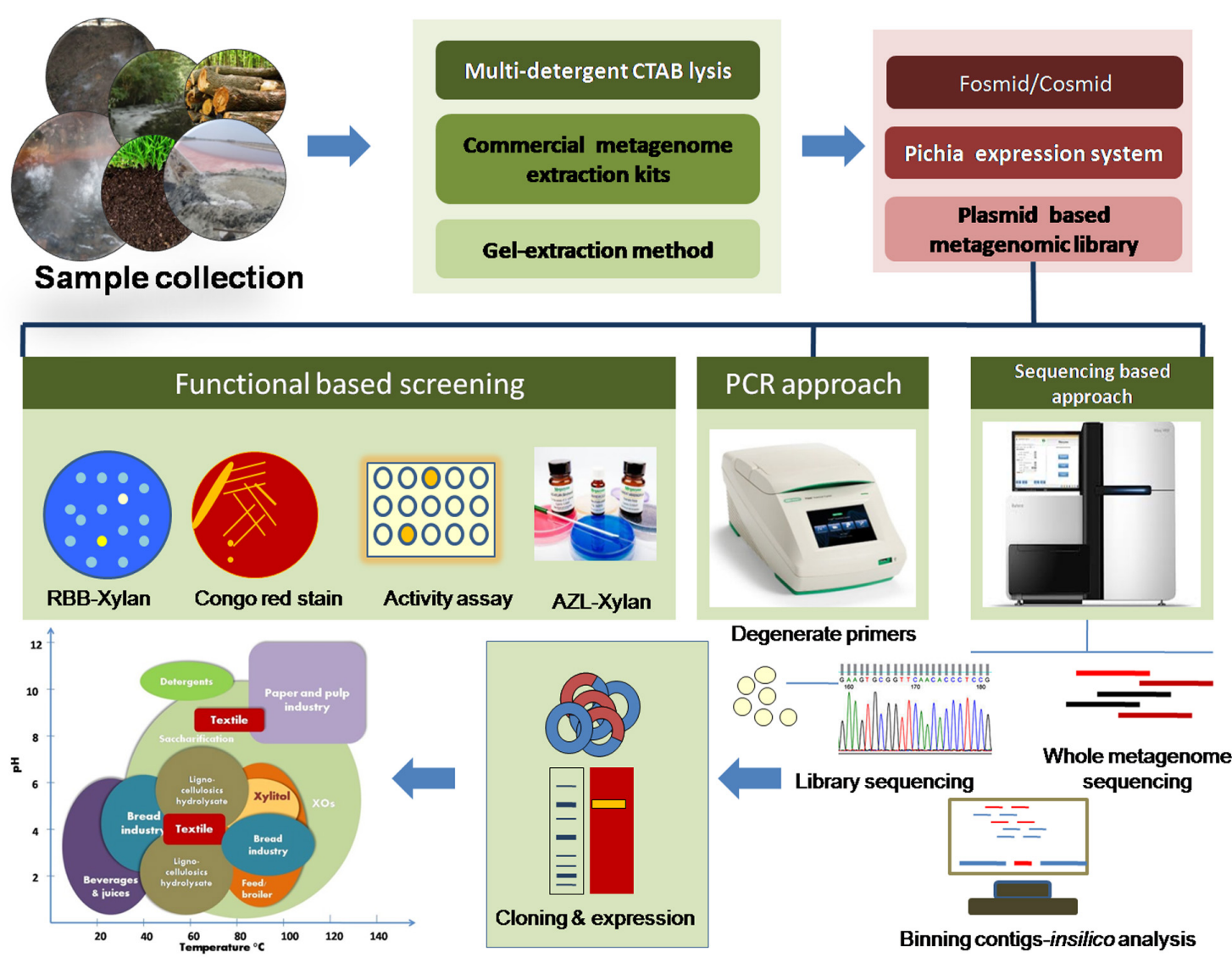

FIGURE 1 | Schematic representation for retrieving xylan-degrading enzymes using metagenomic approaches.

low water activity find multiple applications in food and beverage processing. Microorganisms exhibit a high degree of genomic and metabolic flexibility for adapting to extreme environmental conditions, and therefore, they occur ubiquitously and act as a reservoir for proteins/enzymes capable of withstanding extreme environmental conditions (Badhai et al., 2015). Several extreme environments have been explored for obtaining extremophilic microbes for their exploitation in harnessing extremozymes (Shi H. et al., 2013; Wang et al., 2015). Many xylan-depolymerizing enzymes have also been identified from innumerable prokaryotic and eukaryotic microorganisms from extreme environments (Kumar et al., 2013a; Verma et al., 2019). However, the limitations associated with these microbial enzymes cannot be ignored. Xylanolytic enzymes of bacterial origin are mostly preferred over the fungal xylanases due to the retention of activity by the former under extreme environmental conditions (Kumar et al., 2016). Broad pH and temperature optima and fair stability under extreme conditions in addition to broad substrate specificity make the bacterial xylanases preferable over those from fungi although the production levels are of the former are lower than those of the latter (Verma et al., 2019).

Due to the problems encountered in simulating environmental conditions in the laboratory and limited culturability, we lose a major chunk of microorganisms present in environmental samples. Metagenomics has emerged as an alternative tool for discovering novel bioactive molecules from various environments (Lorenz and Eck, 2005; Berini et al., 2017; Fredriksen et al., 2019). Several novel xylanolytic enzymes with unique properties have also been obtained from various extreme environmental samples using metagenomic approaches. Wang et al. (2016) further emphasize digging out the entire enzyme assemblages from environments that can depolymerize the target complex polysaccharides efficiently. Such a cocktail of enzymes usually share similar biophysical properties due to their common origin, which further enhances their compatibility for complete substrate hydrolysis (Berini et al., 2017). Several such lignocellulases have been successfully derived using the metagenomic approaches (Thidarat et al., 2012; Wang et al., 2015; Liu et al., 2018). Unfortunately, a majority of the discovered xylanolytic enzymes are still uncharacterized, which can be seen in the Carbohydrate Active Enzymes (CAZy) database $^{1}$. In addition, most of those characterized are limited to their biophysical properties only and not well explored for their applicability under industrial process conditions. This review summarizes various facets of metagenomic xylanolytic extremozymes, such as their characteristics, comparison with the available xylan-degrading enzymes, improvement by genetic/protein engineering, and potential applications.

${ }^{1}$ www.cazydatabse.com 


\section{TIMELINE OF METAGENOMIC XYLANOLYTIC ENZYME DISCOVERY}

It took nearly 10 years to report the first xylan-degrading enzyme through the metagenomic approach after its introduction. Sunna and Bergquist (2003) were the pioneers who reported the first xylanase from the hot pool metagenome using a genomewalking PCR (GW-PCR) approach. The retrieved xylanase shared similarity with GH-10 xylanase with unusual features; thus, this can be considered the first report of the GH-10 family xylanase of metagenomic origin. It was followed by Brennan et al. (2004), who reported the first GH-11 and GH-8 xylanases from the insect gut metagenome using direct cloning of the environmental DNA. Lee et al. (2006) reported the second GH-8 xylanase from the lagoon of a dairy farm. The first multifunctional glycosyl hydrolases of GH-5 and GH-26 were reported by Palackal et al. (2007). Attempts have been made for the first time to enhance the sensitivity of PCR using rolling circle amplification of the horse gut metagenome that revealed five GH-10 xylanases (Yamada et al., 2008). Of various environmental samples, the soil was first explored for cloning community DNA by $\mathrm{Hu}$ et al. (2008) to uncover hidden metagenomic xylanases. Similarly, Kwon et al. (2010) investigated the compost soil metagenome and reported five xylanases out of 12,380 fosmid clones. The claim of Jeong et al. (2012) for reporting the first xylanase from the compost metagenomic library, therefore, stands corrected. Verma et al. (2013a) first reported an industrially relevant metagenomic endoxylanase that finds applicability in biobleaching of pulp samples.

A novel xylanosome operon having three contiguous genes of family GH-8, GH-10, and GH-11 was identified from a wood-feeding termite gut metagenome in 2012 (Thidarat et al., 2012). Further, Zhang et al. (2014) studied the role of human gut inhabitant Bacteroidetes by reporting two GH10 family endoxylanases from the human gut metagenome. Several new findings associated with the xylan-depolymerizing enzymes of metagenomic origin have been published during the past 5 years (Wang et al., 2015; Rashamuse et al., 2016; Kim et al., 2018; Ellila et al., 2019; Alves et al., 2020; Victorica et al., 2020; Tables 1, 2). Recently, a novel computational method, thermal activity prediction for xylanase (TAXyl), was developed to predict the thermal activity of GH-10 and GH11 xylanases (Shahraki et al., 2019). Although several xylandegrading enzymes are known today, using culture-independent metagenomic approaches, less than 100 of them have been adequately characterized. Therefore, there is an urgent need to characterize the remaining metagenomic xylanases.

\section{STRATEGIES TO BOOST THE RETRIEVAL OF METAGENOMIC XYLANOLYTIC ENZYMES}

Metagenomics demands a rational approach to attain the desired xylanolytic enzymes, and it starts from sample collection to screening to final retrieval of the genes (Figure 1). The following are the few criteria that should be considered for attaining xylandegrading enzymes from environmental metagenomes.

\section{Selection of the Xylan Substrates}

High-throughput screening strategies enhance the possibility of searching the novel bioactive molecules multifold. For xylanase screening, the traditional Congo red staining method is highly popular; however, it is tedious and laborintensive, as it demands rigorous replica plating for screening metagenomic libraries. Incorporation of Remazol Brilliant Blue (RBB) cross-linked xylan into the cultivation medium makes the screening efficient, and an appropriately diluted library can be screened for detecting colonies displaying a halo zone of xylan hydrolysis. However, RBB-xylan is quite expensive and can be prepared in the laboratory according to the protocol of Bailey et al. (1992). The fluorescence-based method EnzChek ${ }^{\circledR}$ Ultra Xylanase Assay Kit (Invitrogen, Carlsbad, CA, United States) and Xylazyme tablet (Megazyme, Bray, Ireland) account for the other screening techniques; Azurine-crosslinked xylan (AZCL xylan) is employed as dye conjugated substrates (Selvarajan and Veena, 2017). Several clones have shown a blue halo from fosmid-based metagenomic libraries using AZCL xylan (Ellila et al., 2019; Knapik et al., 2019).

Selection of xylan type is also decisive in obtaining positive clones during functional screening. Birchwood xylan and others are recommended over oat-spelt xylan, Larchwood xylan, and arabinoxylan (Shi H. et al., 2013; Verma et al., 2013a). Birchwood xylan comprises the highest amount of xylose sugar with $89.3 \%$ (Kormelink and Voragen, 1993) as compared to beechwood xylan (80.8\% xylose; Megazyme) and arabinoxylan (65.8\% xylose; Gruppen et al., 1992). Functional screening permits recovery of several fulllength metagenomic xylanase-encoding genes by using RBB xylan/AZCL xylan as substrates (Lee et al., 2006; Zhao et al., 2010; Verma and Satynarayana, 2011).

\section{Fosmid Libraries Are the Preferred Choice}

The success rate of functional screening of libraries is significantly higher than the sequence-based approaches in obtaining more positive clones as the latter provides usual partial sequences (Lorenz and Eck, 2005; Berini et al., 2017). Several such metagenomic libraries have been constructed in plasmids (Verma et al., 2013b), cosmids (Mo et al., 2010; Chang et al., 2011; Bao et al., 2012), and fosmids (Jeong et al., 2012; Knapik et al., 2019) for retrieving genes that encode xylan-degrading enzymes (Wang et al., 2015; Kim et al., 2018; Thornbury et al., 2019). Among them, a majority of the metagenomic libraries have been constructed in the fosmid vectors $\left(\mathrm{pCC}^{\mathrm{FOOS}}{ }^{\mathrm{TM}}\right.$ and $\mathrm{pCC} 1 \mathrm{FOS}^{\mathrm{TM}}$ ) with its host strain EPI300-T1R ${ }^{\mathrm{TM}}$, provided by Epicentre, for obtaining genes encoding xylan-degrading enzymes (Jeong et al., 2012; Kim et al., 2018; Liu et al., 2019). Fosmids can harbor large stretches of DNA $(40-60 \mathrm{~kb})$ that enhance the number of positive hits. Alves et al. (2020) report 
TABLE 1 | An update of metagenomic GH-10 and GH-11 endoxylanases.

\begin{tabular}{|c|c|c|c|c|c|c|c|c|c|c|}
\hline S. No. & Source & Name & $\begin{array}{l}\text { Vector/host/ } \\
\text { approaches }\end{array}$ & $\begin{array}{l}\text { Library type/ } \\
\text { approach }\end{array}$ & $\begin{array}{l}\text { Positive } \\
\text { hits }\end{array}$ & Opt $_{p H}$ & $\operatorname{Opt}_{T e m p} \cdot\left({ }^{\circ} \mathrm{C}\right)$ & $\begin{array}{l}\text { Molecular } \\
\text { mass (kDa) }\end{array}$ & Family & References \\
\hline 1. & Camel rumen metagenome & PersiXyn1 & NA & Direct sequencing & & 8.0 & 40 & 43 & $\mathrm{GH}-11$ & Ariaeenejad et al., 2019 \\
\hline 2. & Compost metagenome & XYL21, XYL38 & $\begin{array}{l}\text { CopyControl Fosmid } \\
\text { Library Production kit }\end{array}$ & Fosmid & 40 & $5.5-7.0$ & 80 (XYL38) & 41.9 (XYL38) & $\mathrm{GH}-10$ & Ellila et al., 2019 \\
\hline 3. & Arctic mid-ocean ridge vent & AMOR_GH10A & Metagenomic data set & NA & NA & 5.6 & 80 & & $\mathrm{GH}-10$ & Fredriksen et al., 2019 \\
\hline 4. & Camel rumen metagenome & XylCMS & 454 Pyrosequencing & NA & NA & 6.0 & 55 & 46 & $\mathrm{GH}-11$ & Ghadikolaei et al., 2019 \\
\hline 5. & Lobios hot spring sediment & XynA3 & Fosmid & Fosmid & $1 / 150,000$ & 6.5 & 80 & 41 & $\mathrm{GH}-11$ & Knapik et al., 2019 \\
\hline 6. & Saline-alkaline soil & Xyn22 & pMD18T/E. coli DH5 $\alpha$ & Plasmid & $150 /-$ & 7.0 & 60 & 25 & $\mathrm{GH}-11$ & Li et al., 2019 \\
\hline 7. & Termite gut metagenome & & $\begin{array}{l}\text { CopyControl fosmid } \\
\text { library production kit }\end{array}$ & Fosmid & $101 / 50,000$ & $\begin{array}{l}\text { ORF7: } 7.0 \\
\text { ORF21:7.0 }\end{array}$ & $\begin{array}{l}\text { ORF7: } 60 \\
\text { ORF21: } 60\end{array}$ & $\begin{array}{l}\text { ORF7: } 45 \\
\text { ORF21: } 53.1\end{array}$ & $\mathrm{GH}-10$ & Liu et al., 2019 \\
\hline 8. & $\begin{array}{l}\text { Soda lake Dabusu } \\
\text { metagenome }\end{array}$ & $-\mathrm{NA}-$ & Illumina HiSeq2500 & NA & NA & NA & NA & NA & NA & Wang et al., 2019 \\
\hline 9. & Black goat rumen & KG42 & $\begin{array}{l}\text { CopyControl fosmid } \\
\text { library production kit }\end{array}$ & Fosmid & $17 / 115,200$ & 5.0 & 50 & 41 & $\mathrm{GH}-10$ & Kim et al., 2018 \\
\hline 10. & Termite gut metagenome & Xyl1 & $\begin{array}{l}\text { CopyControl fosmid } \\
\text { library production kit }\end{array}$ & Fosmid & $14 / 40,000$ & 6.0 & 50 & 55 & $\mathrm{GH}-11$ & Rashamuse et al., 2016 \\
\hline 11. & $\begin{array}{l}\text { Hu sheep rumen } \\
\text { metagenome }\end{array}$ & xyn-Ixy & $\begin{array}{l}\text { EpiFOSTM Fosmid } \\
\text { Library Production Kit }\end{array}$ & Fosmid & $18 / 12704$ & 6.0 & 50 & 80 & $\mathrm{GH}-10$ & Wang et al., 2015 \\
\hline 12. & Cattle rumen metagenome & Xyln-SH1 & $\begin{array}{l}\text { EpiFOSTM Fosmid } \\
\text { Library Production Kit }\end{array}$ & Fosmid & $1 /-$ & 6.5 & 40 & 41.5 & $\mathrm{GH}-10$ & Cheng et al., 2012 \\
\hline 13. & Compost soil metagenome & Mxyl & p18GFP vector & Plasmid & $1 / 36,000$ & 9.0 & 80 & 43 & $\mathrm{GH}-11$ & Verma et al., 2013b \\
\hline 14. & $\begin{array}{l}\text { Chicken cecum } \\
\text { metagenome }\end{array}$ & XynAMG1 & $\begin{array}{l}\text { CopyControl fosmid } \\
\text { library production kit }\end{array}$ & Fosmid & NM & 6.0 & 45 & 40 & $\mathrm{GH}-10$ & Al-Darkazali et al., 2017 \\
\hline 15. & Cow dung compost & xyn10CD18 & $\begin{array}{l}\text { PCR approach using } \\
\text { degenerate primers }\end{array}$ & NA & NA & 7.0 & 75 & 43.3 & $\mathrm{GH}-10$ & Sun et al., 2015 \\
\hline 16. & Soil & $\mathrm{XynH}$ & $\begin{array}{l}\text { pHBM803 and } \\
\text { pHBM625/E. coli } \\
\text { BL21(DE3) and } \\
\text { XL10-Gold }\end{array}$ & Plasmid & $1 / 24,000$ & 7.8 & 40 & 39 & $\mathrm{GH}-10$ & Hu et al., 2008 \\
\hline
\end{tabular}


TABLE 1 | Continued

\begin{tabular}{|c|c|c|c|c|c|c|c|c|c|c|}
\hline S. No. & Source & Name & $\begin{array}{l}\text { Vector/host/ } \\
\text { approaches }\end{array}$ & $\begin{array}{l}\text { Library } \\
\text { type/approach }\end{array}$ & $\begin{array}{l}\text { Positive } \\
\text { hits }\end{array}$ & $\mathrm{Opt}_{p H}$ & $\mathrm{Opt}_{T e m p} \cdot\left({ }^{\circ} \mathrm{C}\right)$ & $\begin{array}{l}\text { Molecular } \\
\text { mass (kDa) }\end{array}$ & Family & References \\
\hline 17. & Compost metagenome & Xyn10J & $\begin{array}{l}\text { CopyControl fosmid } \\
\text { library production kit }\end{array}$ & Fosmid & $5 /-$ & 7.0 & 40 & 40 & $\mathrm{GH}-10$ & \\
\hline 18. & Compost metagenome & $\begin{array}{l}X 1, X 2, X 3, X 4 \\
\text { and } X_{5}\end{array}$ & $\begin{array}{l}\text { CopyControl fosmid } \\
\text { library production kit }\end{array}$ & Fosmid & $5 / 12,380$ & $5.5-6.0$ & $50-55$ & ND & ND & Kwon et al., 2010 \\
\hline 19. & $\begin{array}{l}\text { Soil and pulp enrichment } \\
\text { culture }\end{array}$ & $\mathrm{X} 2 \mathrm{P} 1$ & pUC19/E. coli DH5 $\alpha$ & Plasmid & $1 / 40,000$ & ND & ND & ND & ND & Mori et al., 2014 \\
\hline 20. & $\begin{array}{l}\text { Globitermesbrachycerastes } \\
\text { gut metagenome }\end{array}$ & Xyn7 & Fosmid library & Fosmid & ND & 7 & 55 & & $\mathrm{GH}-11$ & Qian et al., 2015 \\
\hline 21. & Termite gut metagenome & xynGH11-7 & $\begin{array}{l}\text { PCR approach using } \\
\text { degenerate primers }\end{array}$ & NA & NA & 6 & 30 & 26.7 & $\begin{array}{l}\mathrm{GH}-11 \text { and } \\
\text { many more }\end{array}$ & Sheng et al., 2015 \\
\hline 22. & Alpine Tundra soil & NM & $\begin{array}{l}\text { PCR approach using } \\
\text { degenerate primers }\end{array}$ & NA & NA & ND & ND & ND & ND & Wang et al., 2010 \\
\hline 23. & POME (Pal oil mill effluent) & $-\mathrm{NM}-$ & $\begin{array}{l}\text { CopyControl fosmid } \\
\text { library production kit }\end{array}$ & Fosmid & $6 /-$ & NM & NM & NM & $\begin{array}{l}\mathrm{GH}-10 \text { and } \\
\text { others }\end{array}$ & $\begin{array}{l}\text { Benbelgacem et al., } \\
2018\end{array}$ \\
\hline 24. & $\begin{array}{l}\text { Fungus-growing termite, } \\
\text { Pseudacanthotermes } \\
\text { militaris }\end{array}$ & Xyn3 & $\begin{array}{l}\text { CopyControl fosmid } \\
\text { library production kit }\end{array}$ & Fosmid & $\begin{array}{c}\text { 42/16,000- } \\
\text { gut } \\
12 / 24,000- \\
\text { comb }\end{array}$ & NM & NM & NM & NM & Bastien et al., 2013 \\
\hline 25. & $\begin{array}{l}\text { Goats ruminal liquid } \\
\text { metagenome }\end{array}$ & $\begin{array}{l}\text { Multiple } \\
\text { xylanolytic } \\
\text { enzymes }\end{array}$ & $\begin{array}{l}\text { CopyControl fosmid } \\
\text { library production kit }\end{array}$ & Fosmid & $\begin{array}{l}\text { 22/15,0000 } \\
\text { endo- } \\
\text { xylanase }\end{array}$ & $5-7$ & 50 & ND & $\mathrm{GH}-11$ & Duque et al., 2018 \\
\hline 26. & $\begin{array}{l}\text { Thermophilic methanogenic } \\
\text { digester community } \\
\text { enriched with paper }\end{array}$ & $\begin{array}{l}\text { Multiple } \\
\text { xylanolytic } \\
\text { enzymes }\end{array}$ & $\begin{array}{l}\text { CopyControl fosmid } \\
\text { library production kit }\end{array}$ & Fosmid & $37 / 9700$ & $5-6$ & $60-75$ & ND & $\mathrm{GH}-11$ & Wang et al., 2015 \\
\hline 27. & $\begin{array}{l}\text { Kinema soyabean } \\
\text { metagenome }\end{array}$ & NM & $\begin{array}{l}\text { Whole metagenome } \\
\text { sequencing }\end{array}$ & NA & NA & ND & ND & ND & $\mathrm{GH}-11$ & Kumar et al., 2019 \\
\hline
\end{tabular}


TABLE 1 | Continued

\begin{tabular}{|c|c|c|c|c|c|c|c|c|c|c|}
\hline S. No. & Source & Name & $\begin{array}{l}\text { Vector/host/ } \\
\text { approaches }\end{array}$ & $\begin{array}{c}\text { Library } \\
\text { type/approach }\end{array}$ & $\begin{array}{l}\text { Positive } \\
\text { hits }\end{array}$ & $\mathrm{Opt}_{p H}$ & $\operatorname{Opt}_{T e m p} \cdot\left({ }^{\circ} \mathrm{C}\right)$ & $\begin{array}{l}\text { Molecular } \\
\text { mass (kDa) }\end{array}$ & Family & References \\
\hline 28. & $\begin{array}{l}\text { Grass hay-fed dairy cow } \\
\text { rumen metagenome }\end{array}$ & xyn10N18 & BAC library & BAC & ND & 6.5 & 35 & 54.5 & $\mathrm{GH}-10$ & Gong et al., 2013 \\
\hline 29. & $\begin{array}{l}\text { Wood-feeding higher } \\
\text { termite }\end{array}$ & X1098.3 & pCC1FOS & Fosmid & $12 / 88,000$ & 8 & 55 & ND & $\begin{array}{c}\mathrm{GH}-10 \text { and } \\
11\end{array}$ & Thidarat et al., 2012 \\
\hline 30. & Sugarcane bagasse & Xyn11 One of 5 & $\begin{array}{l}\text { CopyControl fosmid } \\
\text { library production kit }\end{array}$ & Fomid & 05/120,000 & 6 & 80 & 45 & $\mathrm{GH}-11$ & $\begin{array}{l}\text { Kanokratana et al., } \\
2014\end{array}$ \\
\hline 31. & $\begin{array}{l}\text { Hot springs, Tattapani, } \\
\text { Chhattisgarh }\end{array}$ & $\begin{array}{l}\text { Illumina } \\
\text { HiSeq1000 }\end{array}$ & NA & $\begin{array}{l}\text { MG-RAST and } \\
\text { SEED databases }\end{array}$ & NA & NA & NA & NA & NA & Kaushal et al., 2018 \\
\hline 32. & Rice straw metagenome & Umxyn10A & pWEB:TNC Cosmid & Cosmid & $1 / 12,000$ & 6.5 & 75 & 44 & $\mathrm{GH}-10$ & Mo et al., 2010 \\
\hline 33. & $\begin{array}{l}\text { Cow dung compost } \\
\text { metagenome }\end{array}$ & Xyn10CD18 & $\begin{array}{l}\text { PCR approach using } \\
\text { degenerate primers }\end{array}$ & NA & NA & 7 & 75 & 43.3 & $\mathrm{GH}-10$ & Sun et al., 2015 \\
\hline 34. & Termite gut metagenome & $\begin{array}{l}\text { XYL6806 } \\
\text { XYL6807 } \\
\text { XYL6805 } \\
\text { XYL6419 }\end{array}$ & $\begin{array}{l}\text { pET101/D-TOPO } \\
\text { vector }\end{array}$ & E. coli BL21 & NM & $5-6$ & 50 & NM & $\begin{array}{c}\text { XYL6806: } \\
\text { GH8 Rest } \\
\text { were of } \\
\text { GH11 }\end{array}$ & Brennan et al., 2004 \\
\hline 35. & Cow manure metagenome & manf-x10 & $\begin{array}{l}\text { Lambda ZAP II vector } \\
\text { and Gigapack III } \\
\text { Packaging Extract }\end{array}$ & Bacteriophage & $\begin{array}{l}1 / 2 \times 10^{5} \\
\text { plaque } \\
\text { units }\end{array}$ & 7 & 40 & 50.3 & $\mathrm{GH}-10$ & Li et al., 2009 \\
\hline 36. & $\begin{array}{l}\text { Pawan hot spring } \\
\text { metagenome }\end{array}$ & xyn PW8 & $\begin{array}{l}\text { PCR approach using } \\
\text { GH-11 primers }\end{array}$ & NA & NA & 7.0 & 50 & 23.3 & $\mathrm{GH}-11$ & Helianti, 2007 \\
\hline 37. & $\begin{array}{l}\text { Vermiform appendixes of } \\
\text { horses metagenome }\end{array}$ & XYnVA1 & Inverse PCR (IPCR) & NA & NA & ND & ND & $42-63$ & $\mathrm{GH}-10$ & Yamada et al., 2008 \\
\hline 38. & Hot pool metagenome & NM & $\begin{array}{l}\text { Genomic walking PCR } \\
\text { (GWPCR) }\end{array}$ & NA & NA & 6 & 100 & ND & $\mathrm{GH}-10$ & $\begin{array}{l}\text { Sunna and Bergquist, } \\
2003\end{array}$ \\
\hline 38. & Hot pool metagenome & NM & $\begin{array}{l}\text { Genomic walking PCR } \\
\text { (GWPCR) }\end{array}$ & NA & NA & 6 & 100 & ND & $\mathrm{GH}-10$ & $\begin{array}{l}\text { Sunna and Bergquist, } \\
2003\end{array}$ \\
\hline
\end{tabular}

NM, not mentioned; ND, not determined; NA, not applicable. 
TABLE 2 | An update of metagenomic xylanolytic enzymes other than GH-10 and GH-11 xylanases.

\begin{tabular}{|c|c|c|c|c|c|c|c|c|c|c|}
\hline S. No. & Source & Name & $\begin{array}{l}\text { Vector/host/ } \\
\text { approaches }\end{array}$ & $\begin{array}{c}\text { Library } \\
\text { type/approach }\end{array}$ & Positive hits & $\mathrm{Opt}_{p H}$ & $\begin{array}{l}\text { Opt }_{T e m p} \\
\quad\left({ }^{\circ} \mathrm{C}\right)\end{array}$ & $\begin{array}{l}\text { Molecular } \\
\text { weight (kDa) }\end{array}$ & Family & References \\
\hline 1. & $\begin{array}{l}\text { Yak rumen } \\
\text { metagenome }\end{array}$ & $\begin{array}{l}\text { Rubg3A and } \\
\text { Rubg3B }\end{array}$ & $\begin{array}{l}\text { pWEB Cosmid (Epicentre, } \\
\text { United States) }\end{array}$ & Cosmid & $2 / 4000$ & $4.5-5.5$ & $35-40$ & 80 & $\mathrm{GH}-3$ & Bao et al., 2012 \\
\hline 2. & $\begin{array}{l}\text { Yak rumen } \\
\text { metagenome }\end{array}$ & RuBGX1 & $\begin{array}{l}\text { pWEB Cosmid (Epicentre, } \\
\text { United States) }\end{array}$ & Cosmid & $1 / 5000$ & 6 & 50 & 80 & $\mathrm{GH}-3$ & Zhou et al., 2011 \\
\hline 3. & $\begin{array}{l}\text { Yak rumen } \\
\text { metagenome }\end{array}$ & $\begin{array}{l}\text { RuXyn1 and } \\
\text { RuXyn2 }\end{array}$ & $\begin{array}{l}\text { pWEB Cosmid (Epicentre, } \\
\text { United States) }\end{array}$ & Cosmid & NM & $5.5-7.0$ & $40-55$ & 42 and 50 & $\mathrm{GH}-43$ & Zhou et al., 2012 \\
\hline 4. & $\begin{array}{l}\text { Cow rumen } \\
\text { metagenome }\end{array}$ & RUM630-BX & $\begin{array}{l}\text { Lambda ZAP II Vector and } \\
\text { Gigapack III Packaging Ext., Agilent }\end{array}$ & Lambda phage & NM & 7.0 & 25 & ND & $\mathrm{GH}-43$ & Jordan et al., 2016 \\
\hline 5. & $\begin{array}{l}\text { Termite gut } \\
\text { metagenome }\end{array}$ & Xyl1 and xyl8 & $\begin{array}{l}\text { CopyControl fosmid library } \\
\text { production kit }\end{array}$ & Fosmid & 12/8/12,000 & $5-6$ & $40-50$ & $53-90$ & $\begin{array}{l}\mathrm{GH} 43 \text { and } \\
\mathrm{GH}-3\end{array}$ & Liu et al., 2018 \\
\hline 6. & $\begin{array}{l}\text { Wheat straw } \\
\text { degrading microbial } \\
\text { consortium }\end{array}$ & xylM1989 & Microbial consortium & NA & NA & 8 & 20 & 37.5 & $\mathrm{GH}-43$ & Maruthamuthu et al., 2017 \\
\hline 7. & Soil & MeXyl31 & $\begin{array}{l}\text { CopyControl fosmid library } \\
\text { production kit }\end{array}$ & Fosmid & $1 / 50,000$ & 5.5 & 45 & 77 & $\mathrm{GH}-31$ & Matsuzawa et al., 2016 \\
\hline 8. & Compost & Biof1_09 & $\begin{array}{l}\text { CopyControl fosmid library } \\
\text { production kit }\end{array}$ & Fosmid & $1 /-$ & 4.5 & 50 & 12.8 & $\mathrm{GH}-43$ & $\begin{array}{l}\text { Sae-Lee and Boonmee, } \\
2014\end{array}$ \\
\hline 9. & Hot spring & $\begin{array}{l}\text { AR19M-311-2, } \\
\text { AR19M-311-11 } \\
\text { and, } \\
\text { AR19M-311-21 }\end{array}$ & Direct sequencing & NA & NA & 5 & $50-90$ & & $\begin{array}{c}\mathrm{GH}-1, \\
\mathrm{GH}-3 \text {, } \\
\mathrm{GH}-31 \text {, and } \\
\mathrm{GH}-43\end{array}$ & Sato et al., 2017 \\
\hline 10. & $\begin{array}{l}\text { Compost starter } \\
\text { mixer }\end{array}$ & $\operatorname{deAX}$ & $\begin{array}{l}\text { Lambda ZAP II vector and } \\
\text { packaged into lambda phage }\end{array}$ & $\begin{array}{l}\text { Lambda ZAP ॥ } \\
\text { vector }\end{array}$ & NM & $5.5-7.0$ & 55 & 59.1 & $\mathrm{GH}-43$ & Wagschal et al., 2009 \\
\hline 11. & $\begin{array}{l}\text { Cow rumen fluid } \\
\text { metagenome }\end{array}$ & GH6284 & $\begin{array}{l}\text { Lambda ZAP Express and } \\
\text { Gigapack II Gold Packaging Extract }\end{array}$ & $\begin{array}{l}\text { Lambda phage } \\
\text { library }\end{array}$ & $1 / 50,000$ & 5.8 & 45 & 110.8 & $\begin{array}{l}\mathrm{GH}-5 \text { and } \\
\mathrm{GH}-26\end{array}$ & Palackal et al., 2007 \\
\hline 12. & $\begin{array}{l}\text { Goats ruminal liquid } \\
\text { metagenome }\end{array}$ & $\begin{array}{l}\text { Multiple xylanolytic } \\
\text { enzymes }\end{array}$ & $\begin{array}{l}\text { CopyControl fosmid library } \\
\text { production kit }\end{array}$ & Fosmid & $\begin{array}{c}\text { 22/150,000 } \\
\text { endo-xylanase } \\
\text { 125/150,000 } \\
\text { xylosidase }\end{array}$ & $5-7$ & 50 & ND & $\begin{array}{c}\mathrm{GH}-1, \\
\mathrm{GH}-5, \\
\mathrm{GH}-8, \\
\mathrm{GH}-14 \text {, and } \\
\mathrm{GH}-43\end{array}$ & Duque et al., 2018 \\
\hline 13. & $\begin{array}{l}\text { Kinema soyabean } \\
\text { metagenome }\end{array}$ & NM & Whole metagenome sequencing & NA & NA & ND & ND & ND & $\begin{array}{l}\text { GH39 and } \\
\text { GH } 43\end{array}$ & Kumar et al., 2019 \\
\hline 14. & $\begin{array}{l}\text { Chinese holstein } \\
\text { dairy cow rumen }\end{array}$ & UX66 & $\begin{array}{l}\text { CopyControl pCCIBAC vector and } \\
\text { E. coli }\end{array}$ & BAC & $18 / 15,360$ & 6 & 50 & 63 & $\mathrm{GH}-43$ & Zhao et al., 2010 \\
\hline 15. & $\begin{array}{l}\text { Lagoon of dairy } \\
\text { farm }\end{array}$ & Xyn8 & $\begin{array}{l}\text { Lambda ZAP II Vector/lambda } \\
\text { phage }\end{array}$ & Fosmid & - & $6-7$ & 20 & 45.9 & $\mathrm{GH}-8$ & Lee et al., 2006 \\
\hline
\end{tabular}


three potential candidates for xylanolytic enzymes (MgrBr18, MgrBr61, and MgrBr135) out of the 12,960 fosmid clones having an average insert size of $40 \mathrm{~Kb}$. Similarly, 17 novel positive xylanolytic clones were obtained out of 1,15,200 clones from a fosmid-based library (average inert size $30.5 \mathrm{~kb}$ ). Of the 17 clones, one clone, KG42, revealed the highest xylanase (GH-10 family) activity under acidic conditions (Kim et al., 2018). In another report, a pCT3FK fosmid vector was used to construct $1,50,000$ clones, and one positive clone (XylA3) has been identified for xylanase activity (Knapik et al., 2019). Rashamuse et al. (2016) identified several glycosyl hydrolasepositive clones from a fosmid-based metagenomic library of 40,000 clones. The high positive hit rate was also achieved by Liu et al. (2019) on large-scale screening of approximately 50,000 fosmid clones, in which 464 displayed polysaccharide hydrolyzing activity. Of these, 101 clones displayed endoxylanase activity.

Plasmid-based metagenomic libraries have also emerged successfully in retrieving xylanolytic enzyme-encoding genes (Lee et al., 2006; Wang et al., 2015). One positive xylanolytic clone was attained from the p18GFP vector by screening 36,000 clones constructed from a soil-compost metagenomic library (Verma et al., 2013b). The success rate of plasmid-based metagenomic libraries is low as compared to the fosmid- and cosmid-based libraries; this is, however, one of the cost-effective processes of routine molecular biology laboratories in digging out novel bioactive molecules.

\section{Mining Genes Using Degenerate Primers}

PCR is another popular approach for exploring community DNA cost-effectively for retrieving hidden genes. Several such reports are available in which degenerate as well as specific sets of primers have been successfully used for amplifying novel xylanase-encoding genes from the metagenomes (Liu et al., 2005; Helianti, 2007; Sheng et al., 2015). The degenerate primers often enhance the possibility of fishing out novel candidates over the specific primers (Sheng et al., 2015). In a pioneering report, Sunna and Bergquist (2003) employed GW-PCR to amplify hidden xylanase genes from the hot pool metagenome in New Zealand. A total of 60 xylanolytic genes have been amplified from the gut metagenome of Holotrichia parallela larvae using degenerate primers, in which 19 gene products belonged to the GH-10 family, 14 were of GH11 type, and the remaining genes showed similarity with the sequences of the GH-8 family (Sheng et al., 2015). Similarly, the metagenome of Alpine tundra soil revealed 96 different xylanases of the GH-10 family using a primer based approach, and 31 showed similarity with the members of the GH-11 family (Wang et al., 2010).

Metagenomes pose an issue for the occurrence of a low abundance of the representative genes, especially from extreme environments due to low microbial biomass. To overcome this, rolling circle amplification has been successfully employed to achieve 11 unique putative GH-10 xylanase genes (Yamada et al., 2008). One major drawback associated with PCRbased approaches is retrieving partial genes that chiefly remain uncharacterized.

\section{Library Sequencing/Whole Metagenome Sequencing}

Direct sequencing of the randomly picked clones from a metagenomic library is a straightforward approach to decode the hidden information in the sequences. This approach has also been employed in generating significant information for hundreds of xylanolytic enzyme-encoding genes (Sato et al., 2017; Ariaeenejad et al., 2019). The direct sequencing of a porcupine metagenome uncovered four genes having $\beta$ glucosidase, $\alpha$-L-arabinofuranosidase, $\beta$-xylosidase, and endo1,4- $\beta$-xylanase activities (Thornbury et al., 2019). Whole metagenome sequencing is a relatively more powerful technique over library sequencing to construe the hidden insights of the microbial communities as well as their functional characteristics (Sharpton, 2014; Wiseschart et al., 2019). This technique has been adopted to decipher xylan-depolymerizing enzymeencoding genes from different environmental metagenomes (Wang et al., 2015; Haro-Moreno et al., 2018; Lee et al., 2018; Victorica et al., 2020). Wang et al. (2015) reported four $\beta$ xylosidases using shotgun sequencing of compost metagenome. A unique bifunctional cellulase-xylanase was identified by shotgun sequencing of a goat rumen metagenome (Lee et al., 2018). Although a sequence-based approach often emerges with a plethora of unique information, it demands extensive bioinformatics analysis over functional screening.

\section{PROTEIN ENGINEERING OF METAGENOMIC ENDOXYLANASE}

The metagenomic approach has been used to obtain the best-fit enzymes from metagenomes. Several reports focus on genetic manipulations in order to improve the characteristics of metagenomic xylanolytic enzymes (Verma et al., 2019). Unusual metagenomic xylanase (Mxyl) is further improved by site-directed mutagenesis in which four cumulative replacements of surface serine and threonine residues with arginine enhanced the $\mathrm{T}_{1 / 2}$ of the muteins by 10 and $5 \mathrm{~min}$ at 80 and $90^{\circ} \mathrm{C}$, respectively (Verma et al., 2013b). Similar findings have been reported by Turunen et al. (2002), who replaced multiple serine/threonine surface residues of Trichoderma reesei xylanase with arginine. The high $\mathrm{pKa}$ value of arginine enhances the overall hydrophobicity of the mutated xylanases (Verma et al., 2013a). Such multiple mutations have not been reported for enhancing the thermo-tolerance of endoxylanase II; this also shifted its optimum $\mathrm{pH}$ from neutral to the alkaline region. Sriprang et al. (2006) also report the improvement of xylanases using site-directed mutagenesis by multiple substitutions of arginine on protein surfaces. Another metagenome-derived xylanase (Xyn7) was engineered using error-prone PCR, wherein two mutants (XYL7-TC and XYL7-TS) showed a shift in optimum temperature by $10^{\circ} \mathrm{C}$ with an overall enhancement of 250 -fold in their halflives at $55^{\circ} \mathrm{C}$ (Qian et al., 2015). The generation of multiple hydrophobic interactions in mutated xylanase, especially between Met50 and other aromatic amino acids, improved 
the thermostability significantly (Qian et al., 2015). A recently developed in silico web tool, TAXyl, assists in predicting the thermal attributes associated with thermophilic and hyperthermophilic xylanases (Shahraki et al., 2019). There are a few reports on the engineering of metagenomic xylanolytic enzymes; a majority of metagenomic xylanases are still awaiting their characterization.

\section{SAMPLE SOURCES AND THE CHARACTERISTICS OF METAGENOMIC XYLANOLYTIC ENZYMES}

Soil (Li et al., 2019), compost (Jeong et al., 2012), and gut (Shi et al., 2011) are the three most highly explored habitats for harvesting xylan-degrading enzyme-encoding genes in metagenomics. Compost soil grabbed attention due to the high load of microbial biomass and unique biochemical properties. Jeong et al. (2012) exploited a compost metagenome to retrieve xylanolytic enzyme-encoding genes. A majority of the xylanhydrolyzing enzymes recovered from the compost displayed optimum activity in acidic/neutral conditions (Matsuzawa et al., 2015; Sun et al., 2015). Kwon et al. (2010) recovered five acidic and thermophilic xylanase-encoding genes from pig manure and mushroom cultivation residues. A novel xylanase-encoding gene $(M x y l)$ from a compost-soil metagenome was found suitable for bleaching of paper pulp samples. This is one of the rare xylanases that exhibits optimum activity at $80^{\circ} \mathrm{C}$ and alkaline $\mathrm{pH}$ of 9.0 with exceptional thermo-stability $\left.\left[\mathrm{T}_{1 / 2}\left(80^{\circ} \mathrm{C}\right) 120 \mathrm{~min}\right)\right]$ and alkalistability ( $\mathrm{pH}$ 9.0), the desired conditions for biobleaching of paper pulp samples (Verma et al., 2013b). A majority of the existing xylanases do not exhibit such twin stabilities from culturable microbes (Shi et al., 2014; Yan et al., 2017). A few reports discuss the stabilities of xylanases at higher temperatures and $\mathrm{pH}$, obtained through traditional cultural approaches (Mamo et al., 2006; Verma and Satyanarayana, 2012; Kumar and Satyanarayana, 2014). Several xylanases have been recovered from metagenomes having an optimum temperature of $70^{\circ} \mathrm{C}$ or beyond (Sunna and Bergquist, 2003; Kanokratana et al., 2014; Sun et al., 2015; Amel et al., 2016; Ellila et al., 2019; Fredriksen et al., 2019; Knapik et al., 2019). However, the majority of them exhibit their optimum $\mathrm{pH}$ from acidic to neutral range (5.0-7.0) (Mo et al., 2010; Ellila et al., 2019).

Thermostable and acid-stable xylanases have direct applicability in food and feed industries as well as extraction/clarification of fruit juices (Ngara and Zhang, 2018; Verma et al., 2019). Similarly, several alkaliphilic xylanases have been discovered from direct cloning of environmental DNA (Hu et al., 2008; Thidarat et al., 2012; Ariaeenejad et al., 2019; Liu et al., 2019). Camel rumen metagenome-derived xylanase (PersiXyn1) also shows an optimum $\mathrm{pH}$ of 8.0 ; it, however, exhibits optimum activity at $40^{\circ} \mathrm{C}$ (Ariaeenejad et al., 2019). Metagenomic xylanases reported by Thidarat et al. (2012) and Liu et al. (2019) share similar properties having optimum temperature in the range of $55-60^{\circ} \mathrm{C}$ and a $\mathrm{pH}$ of 8.0. Interestingly, both of these xylanases have been recovered from termite gut metagenomes.
The gut of insects and herbivores is the well-explored reservoir for a variety of lignocellulose-degrading enzymes (Leth et al., 2018; Table 1). Shi et al. (2011) stress exploring Orthoptera (grasshoppers) and Coleoptera (woodborers) over the Lepidoptera (leaf-consuming insects) to harvest more potent xylanases. It indicates that these insects degrade a more complex form of lignocellulosic materials. Comparative characteristics of the majority of the insect gut xylanases uncovered are acidic and thermophilic xylanases (Brennan et al., 2004; Qian et al., 2015). GH-11 xylanase (xyl7) from termite gut shows enzymatic activity in a broad range of pH (Qian et al., 2015). Similarly, Sheng et al. (2015) recovered numerous clones having xylanase activity from the gut of $H$. parallela larvae, in which a total of $19 \mathrm{GH}-10,14$ GH-11, and 27 GH-8 xylanases were identified.

Halophilic/halotolerant xylanases show immense applications in the processing of seafood and clarification of juices and wine (Wang et al., 2016; Alokika et al., 2018). Metagenomics has dug out numerous halotolerant xylanolytic enzymes from different environmental sources (Al-Darkazali et al., 2017; Fredriksen et al., 2019; Ghadikolaei et al., 2019; Li et al., 2019; Alves et al., 2020). Metagenomic xylanase from alkaline-saline soil has shown the ability to retain $80 \%$ of its activity at $3 \mathrm{M} \mathrm{NaCl}$. On further characterization, this thermostable xylanase reveals that the surface glutamates (E137 and E139) play a key role in its halotolerance and halostability (Li et al., 2019). Chicken cecum metagenome is also shown to be the source of highly halotolerant xylanase that retains $96 \%$ activity at $4 \mathrm{M} \mathrm{NaCl}$ (Al-Darkazali et al., 2017).

Other environmental samples, such as soil, sediment, water, and effluent, from extreme as well as normal habitats have also been explored for xylan-depolymerizing enzymes (Lee et al., 2006; Hu et al., 2008; Wang et al., 2010; Li et al., 2019; Alves et al., 2020). Several cold-active GH-10 and GH11 xylanase-encoding genes have been retrieved from tundra soil; xylanases displayed cold adaptation (Wang et al., 2010). In a recent report, three potent xylanolytic clones were recovered from mangrove soil metagenomes (Alves et al., 2020). Overall, the majority of the uncovered metagenomic xylanases to date are acidophilic, and their optimum temperature ranges from mesophilic to thermophilic.

\section{UNUSUAL METAGENOMIC XYLANOLYTIC ENZYMES}

The culturable and metagenomic approaches exploit the same environment for mining the genes; therefore, comparing their properties does not look convincing. We cannot ignore that metagenomics also uncovered several hidden genes that we usually lose by routine microbiological culture-dependent methods. Therefore, it is quite interesting to figure out the characteristics of such xylanases and also identify the new additions in terms of their industrial prospects.

A hot pool environmental metagenome uncovered thermostable xylanases having optimum activity at $100^{\circ} \mathrm{C}$; the rarest property among the existing xylanases (Sunna and Bergquist, 2003). Though several features of this xylanase are 
comparable with that of Thermotoga spp., its metagenome did not amplify any of its representative sequences (Thermotogales) on 16S rRNA gene amplification. A majority of the xylanases of Thermotoga spp. are remarkable in exhibiting optimum xylanase activity at or above $80^{\circ} \mathrm{C}$ (Simpson et al., 1991; Sunna and Antranikian, 1997; Shi et al., 2014). Compost soil usually emerges with acidophilic xylanases (Kwon et al., 2010; Sae-Lee and Boonmee, 2014; Ellila et al., 2019). Several metagenomic xylanases display very similar properties and harmonize the acidic characteristics of the compost. However, metagenomic xylanase (Mxyl) is an exception for exhibiting notable thermostability at $80^{\circ} \mathrm{C}$ and alkalistability $(\mathrm{pH}$ 9.010.0) (Verma et al., 2013b). This is the only report from metagenomics for exhibiting dual stabilities at higher $\mathrm{pH}$ and temperature in an endoxylanase. Despite its high molecular weight, it has been categorized into the GH-11 family on the basis of hydrophobic cluster analysis. The endoxylanase of Geobacillus thermoleovorans (Sharma et al., 2007; Verma and Satyanarayana, 2012), Bacillus halodurans S7 (Mamo et al., 2006), B. halodurans TSEV1 (Kumar and Satyanarayana, 2014), Microcella alkaliphila JAM-AC0309 (Kuramochi et al., 2016), and Geobacillus thermodenitrificans TSAA1 (Anand et al., 2013) display such twin properties; however, their stabilities compromise at higher $\mathrm{pH}$ and temperature in the long-run processes and are suitable for industries, especially biobleaching of pulp. Therefore, Mxyl could be a potential candidate for the paper industry. Another unusual metagenomic xylanase (xyn8) from an environmental DNA library shows a distinct optimum temperature of $20^{\circ} \mathrm{C}$, which is quite rare from the culture-dependent approach (Zhao et al., 2010).

A majority of metagenomic psychrophilic xylanases share similar properties with the cold-active xylanases of bacteria/fungi (Lee et al., 2006; Guo et al., 2009; Wang et al., 2010). More efforts are, therefore, needed that suit extreme cold environments for retrieving psychrophilic/psychrotolerant xylanolytic enzymes. Furthermore, a unique bifunctional xylanase/endoglucanase from a yak rumen metagenome has been revealed to exhibit a synergistic effect with $\beta$-1,4-xylosidase and $\beta$-1,4-glucosidase; these are considered ideal candidates for the bioethanol industry (Chang et al., 2011). The bifunctional xylanases also enhance feed nutrient digestibility multifold over the mono-functional xylanases for use in enzyme cocktails (Khandeparker and Numan, 2008).

The discovery of unique halophilic/halotolerant xylanolytic enzymes further enhances the significance of metagenomics. Camel rumen metagenome revealed a rare halophilic xylanase that gets stimulated by $132 \%$ in the presence of $5 \mathrm{M} \mathrm{NaCl}$, which is the highest reported among the various other existing xylanases from culturable approaches to date (Ghadikolaei et al., 2019). In a recent investigation, novel xylanase (AMOR_GH10A) was identified from the Arctic Mid-Ocean Ridge vent system that exhibited dual binding affinity on xylan as well as glycans. On sequencing analysis, its carbohydrate-binding domain (CBD) does not share any similarity with any of the existing sequences available in the databases (Fredriksen et al., 2019). This paved the way to search for new candidates of the CBM85 family that have promising substrate affinities. A unique feature has been reported for the first time from an exceptional metagenomic xylanase (UX66) that comprises two CBDs and two catalytic domains (Zhao et al., 2010). Another unique three catalytic domain multi-enzyme (a CE1 ferulic acid esterase, a GH62 $\alpha$ L-arabinofuranosidase, and a GH10 $\beta$-D-1,4-xylanase) has been recovered from the metagenome of wastewater treatment sludge (Holck et al., 2019). Such attributes enhance the applicability of xylanase manifold over the xylanases having one single catalytic domain. Undoubtedly, metagenomics has emerged as an exceptional tool for adding several novel and unique xylan degrading biocatalysts that find potential in different industries.

\section{ADDITION OF NOVEL METAGENOMIC XYLANASE-ENCODING GENES INTO THE CAZY DATABASE}

Sequencing analysis of the retrieved metagenomic xylanase proteins uncovers a plethora of genes that were inaccessible earlier. The CAZy database comprises several representatives of metagenomic xylanolytic enzymes that are categorized into GH10 and GH-11 families. Approximately 470 endo-acting xylanases are present in the $\mathrm{GH}-10$ and $\mathrm{GH}-11$ families of metagenomic origin; most of them are uncharacterized partial fragments of less than 100 amino acids. Similarly, $\beta$-xylosidases also account for 28 unclassified candidates. The blastp analysis of these sequences reveals that metagenome-originated xylanases share low/high percentage identity from their homologue sequences available in the databases (Mo et al., 2010; Bastien et al., 2013; Rashamuse et al., 2016; Ellila et al., 2019). The phylogenetic tree further depicts clustering of the sequences (full length/partial) into respective GH families (Figure 2); nine partially redundant endoactive xylanases and five arabinosidase/xylosidase metagenomic fragments with very high identity, in which most of the sequences display similarity with the homologue sequences of Bacteroidetes; an overrepresented group of termite gut (Bastien et al., 2013).

A gene derived from a $\mathrm{Hu}$ sheep rumen metagenome shares $97 \%$ identity with a contig 1552 of an uncultured bacterium; its xylanase, however, shows very little similarity with the homologous proteins (Wang et al., 2019). Metagenomic xylanase Xyn10CD18 shares a maximum identity of $83 \%$ with thermostable xylanase of Bacillus sp. N16-5 (Sun et al., 2015). Similarly, the xylanase gene retrieved from a Pawan hot spring metagenome also shares an identity of 95\% with its protein homologue (accession number: CAA84276) (Helianti, 2007). It may be due to the PCR approach to fetch the desired genes, when the specific and degenerate sets of primers are designed from the available gene sequences (Verma et al., 2019). In addition, numerous metagenomic xylanolytic enzymes have also been identified for showing low to very low percentage identity with their homologues (Ellila et al., 2019). Metagenomic xylanase (Xyn38) shares only 50.3\% identity with the GH-10 xylanase of Acidothermus cellulolyticus 11B (Ellila et al., 2019). AMOR_GH10A shares a maximum of $42 \%$ identity with a hypothetical protein from a Verrucomicrobia (Fredriksen et al., 2019). However, its GH-10 domain shows an even lesser identity of $24-28 \%$ with the homologous xylanases. Similarly, KG42 (Kim 


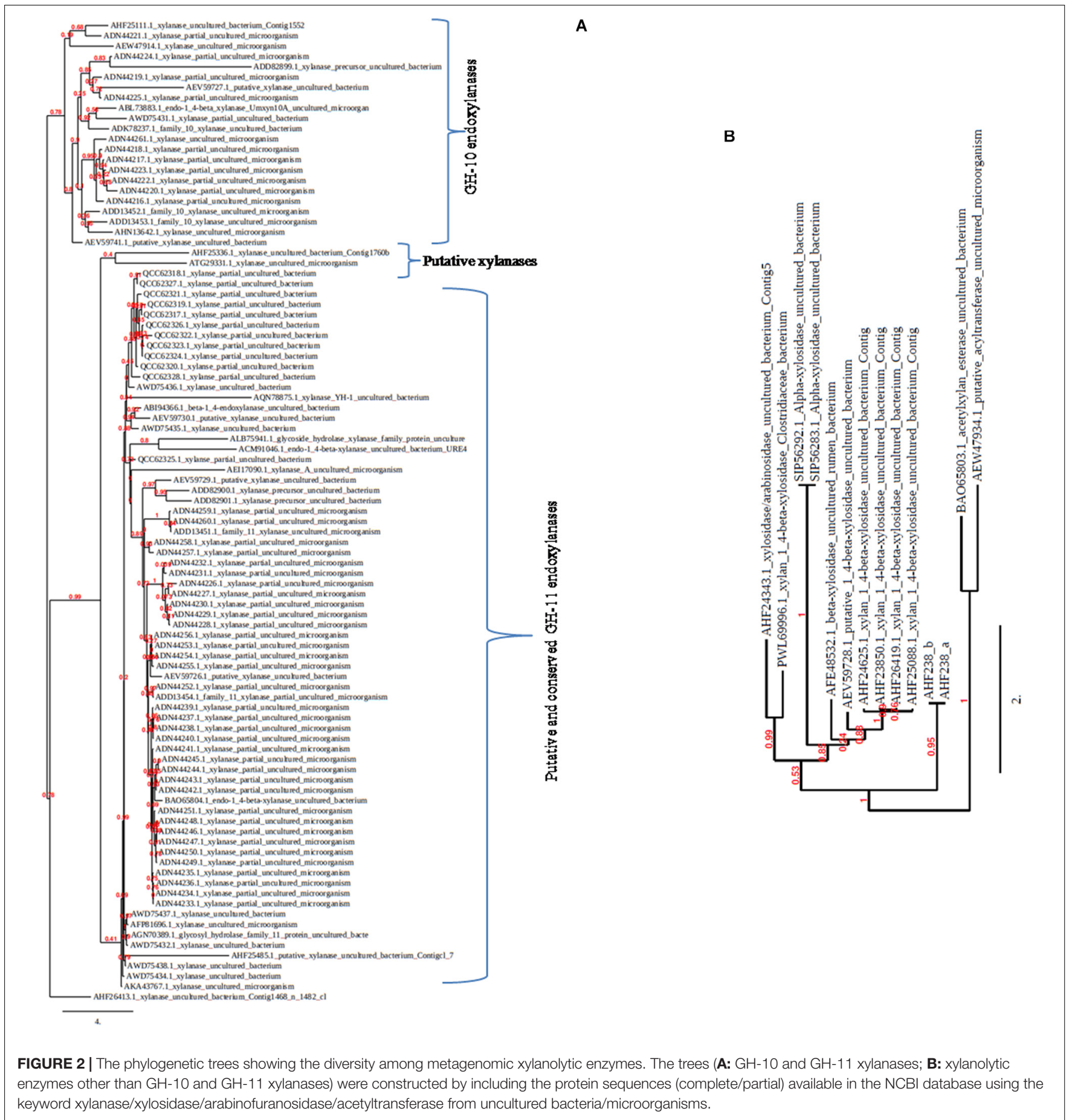

et al., 2018), XYL6806 (Brennan et al., 2004), and xyn10N18 (Gong et al., 2013) xylanases also share a very low identity of merely $40 \%$ with the homologue sequences. The discovery of bifunctional cellulase-xylanase also shows a low identity of $41 \%$ with Cel5 homologues (Lee et al., 2018).

On the contrary, the metagenomic xylanase $(\mathrm{XynH})$ shares a higher identity of $56 \%$ and a similarity of $71 \%$ with the GH-10 family xylanase of Cellvibrio mixtus (accession number
AF049493; Hu et al., 2008). Similarly, umxyn10A shares 58\% identity and $73 \%$ similarity with xylanase from a bacterium Thermobifida fusca (Mo et al., 2010). Five novel xylanase genes having a $35-40 \%$ sequence identity have been retrieved from the PCR-based approach using a horse vermiform appendix metagenome, which is quite surprising (Yamada et al., 2008). Multiple sequence alignments, however, have detected the crucial catalytic residues (glutamate and aspartate) in the 
signature sequences of xylanolytic enzymes of metagenomic origin (Figure 3).

\section{METAGENOMIC $\beta$-XYLOSIDASES AND THEIR CHARACTERISTICS}

Among xylanolytic enzymes, $\beta$-xylosidases (Exo-1, 4- $\beta$ D xylosidase E.C. 3.2.1.37) are the second most highly important xylan-depolymerizing enzymes that assist in complete degradation of xylans. These exotype glycosidases cleave the glycosidic linkages of short xylooligosaccharides (XOs) and liberate the pentaose sugar (xylose) as an end product (Shallom and Shoham, 2003; Jain et al., 2015). Pharmaceutical and food industries demand thermostable and halophilic $\beta$-xylosidases (Jain et al., 2014). Existing $\beta$-xylosidases are associated with several limitations, such as poor efficiency, low thermostability, salt sensitivity, and by-product inhibition (Bao et al., 2012; Anand et al., 2013). Therefore, efforts have been made to discover novel candidates of $\beta$-xylosidases using metagenomic approaches, with which little success has been achieved (Wagschal et al., 2009; Jordan et al., 2016; Cheng et al., 2017; Sato et al., 2017; Liu et al., 2018; Rohman et al., 2019; Table 2). Of the available metagenomic $\beta$-xylosidases, fewer than 20 have been extensively characterized to date. The majority of such $\beta$-xylosidases have been reported from the ruminal fluid of yak (Zhou et al., 2011, 2012; Bao et al., 2012), cow (Jordan et al., 2016), and buffalo (Singh et al., 2014) due to the abundance of hemicellulose-degrading microbes in their guts. Other promising environmental sources have also been explored, such as soil (Matsuzawa et al., 2016) and compost (Sae-Lee and Boonmee, 2014; Matsuzawa et al., 2015; Wang et al., 2015), for harnessing hidden $\beta$-xylosidase genes. On characterization, most of the $\beta$-xylosidases show

(GH-10
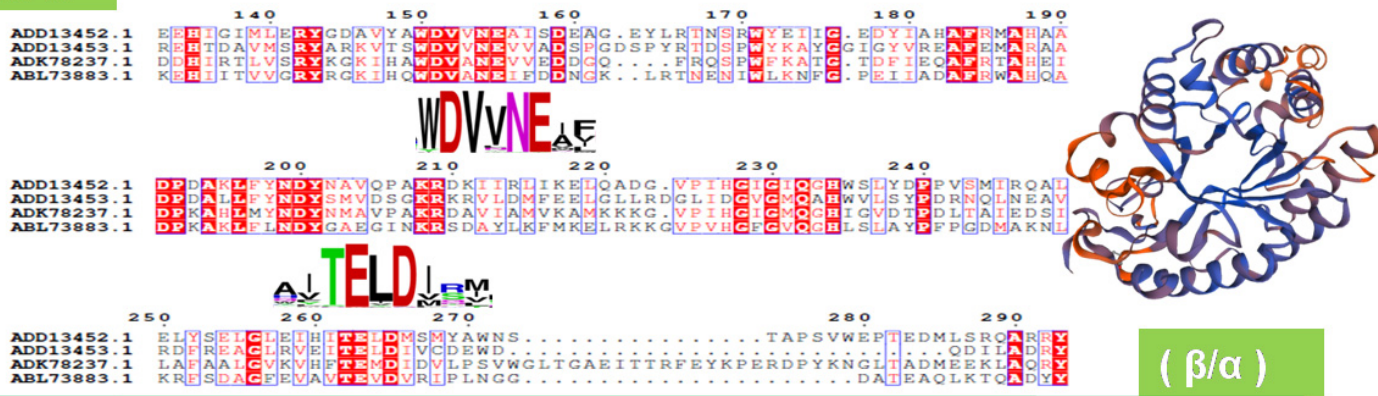

B

\section{(애-141}
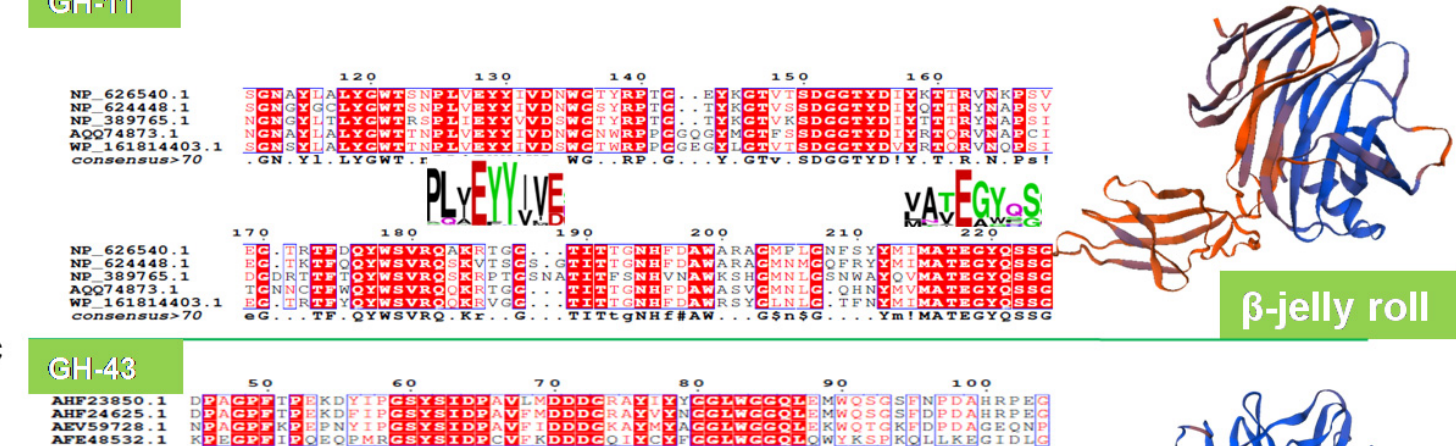

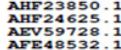
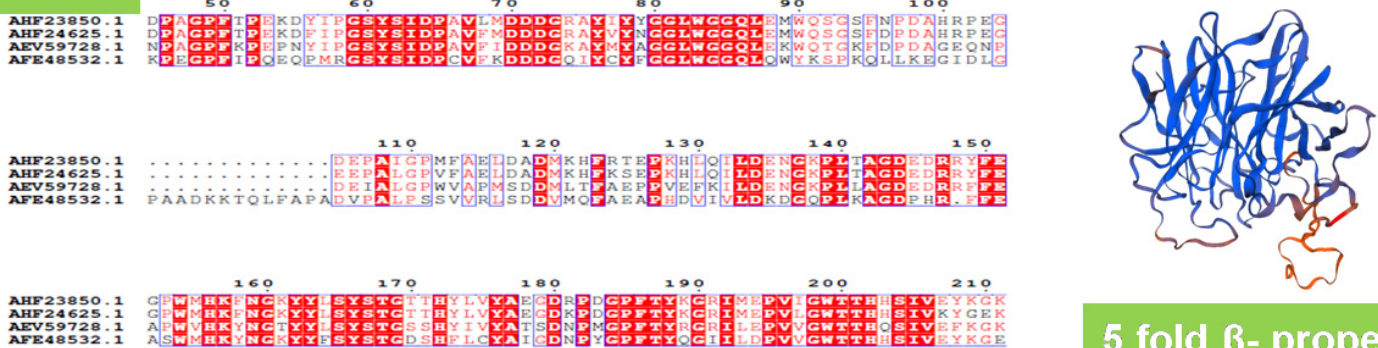

5 fold $\beta$ - propeller

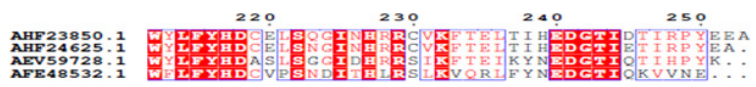

FIGURE 3 | Structure analysis of metagenomic xylanolytic enzymes. The ESPRipt analysis showing the conserved motifs for (A) GH-10 (WDVNEI/A and TEL/MDM/I), (B) GH-11 (PLY/AEYYI/NE/D and ATEGYQ) endoxylanases, and (C) GH-43 (DDDG and LFYI). The GH-10 and GH-11 xylanases exhibited conserved motifs having highly conserved catalytic glutamate $(\mathrm{E})$ and aspartate $(\mathrm{D})$ residues. The signature structure of metagenomic GH-10 (Accession number: ADK78237.1), GH-11 (accession number: AQQ74873.1), and GH-43 (accession number: AFE48532.1) enzymes. 
optimum $\mathrm{pH}$ from an acidic to neutral range (Wagschal et al., 2009; Jordan et al., 2016; Liu et al., 2018). Three highly acidic $\beta$-xylosidases (AR19M-311-2, AR19M-311-11, and AR19M31121) derived from a hot spring metagenome show optimum $\mathrm{pH}$ of 5.0 (Sato et al., 2017). The yak rumen metagenome revealed many acidic $\beta$-xylosidases, and one of the $\beta$-xylosidases (RuBG3A) exhibited activity at pH 4.5 on pNPG. There is only one report of metagenomic $\beta$-xylosidase (xylM1989) that shows its optimum activity at an alkaline $\mathrm{pH}$ of 8.0 (Maruthamuthu et al., 2017).

Thermostable $\beta$-xylosidases are in high demand in industries to overcome microbial contamination and reduce the viscosity of the reaction mixture, which improves the overall reaction efficiency manifold (Haki and Rakshit, 2003). The $\beta$-xylosidases (AR19M-311-2, AR19M-311-11, and AR19M311-21) reported by Sato et al. (2017) are highly thermostable having optimum activity at $90^{\circ} \mathrm{C}$ with fair stability at $70^{\circ} \mathrm{C}$ for $1 \mathrm{~h}$. It corroborates the characteristics of thermostable $\beta$-xylosidases of Thermoanaerobacter ethanolicus, Thermotoga maritima, and Thermotoga thermarum having the temperature optima at and above $90^{\circ} \mathrm{C}$ (Shao and Wiegel, 1992; Shi W. et al., 2013). In another report, four thermostable $\beta$-xylosidases have been reported from a compostsoil metagenome that show optimum activity at $60-75^{\circ} \mathrm{C}$ (Wang et al., 2015). In addition, these $\beta$-xylosidases are found to retain $80 \%$ of residual activity at $50^{\circ} \mathrm{C}$ after $2 \mathrm{~h}$ of incubation. A novel and first metagenomic $\alpha$-xylosidase (MeXyl31) of the GH-31 family has been reported from a soil metagenome that shows an optimum temperature of $45^{\circ} \mathrm{C}$ (Matsuzawa et al., 2016).

Several $\beta$-xylosidases and metagenomic $\beta$-xylosidases have also been identified for their bifunctional enzymatic activities (DeCastro et al., 2016; Rohman et al., 2019). Such $\beta$-xylosidases find applicability in bioethanol production along with the endo-xylanases for efficient release of sugars from the hemicellulose component of agro-residues (Sae-Lee and Boonmee, 2014; Wang et al., 2015). The bifunctional $\beta$-glucosidase/xylosidase activity has been observed in Rubg3A, Rubg3B, and RubGX1 (Zhou et al., 2011; Bao et al., 2012). Many $\beta$-xylosidases derived from the functional screening of the metagenomic library also detected arabinofuranosidase activity (Wagschal et al., 2009; Wang et al., 2015; Jordan et al., 2016). On characterization, $\beta$-xylosidases/arabinofuranosidase (RUM630-BX) enhanced activity 84 -fold due to the stimulation by divalent metal ions $\left(\mathrm{Ca}^{2+}, \mathrm{Co}^{2+}, \mathrm{Fe}^{2+}, \mathrm{Mg}^{2+}, \mathrm{Mn}^{2+}\right.$, and $\mathrm{Ni}^{2+}$ ) (Jordan et al., 2016). Jordan et al. (2018) revealed the role of aspartate and histidine residues at the active site that chelates $\mathrm{Ca}^{2+}$. Therefore, on supplementation of the divalent ions, the overall $\beta$-xylosidase activity was restored. The termite gut metagenome revealed a multimeric $\beta$ xylosidase having a catalytic activity of $\beta$-glucosidase or $\beta$-arabinosidases among four of the positive clones (Liu et al., 2018). A majority of the reported metagenomic $\beta$ xylosidases can be considered as novel due to their unique features along with very low sequence identity/similarity with their homologues.

\section{METAGENOMIC ARABINOFURANOSIDASE AND ACETYL XYLAN ESTERASE}

$\alpha$-L-arabinofuranosidase (EC 3.2.1.55) represents another important class of hemicellulose-degrading enzymes that release arabinofuranosyl side moieties from a heteroxylan by cleaving $\alpha-1,2$ and $\alpha-1,3$ glycosidic bonds (Bouraoui et al., 2013; Kumar et al., 2013b). In addition, non-acetylated heteroxylans have direct access for their backbone-hydrolyzing enzymes, such as endoxylanases and $\beta$-xylosidases (Rennie and Scheller, 2014). More often, $\alpha$-L-arabinofuranosidase acts synergistically along with the cocktail of different xylanolytic enzymes. It finds applications in biomass conversion, food and feed industries, and environmental waste management (Wilkens et al., 2017; Verma et al., 2019). Metagenomic approaches have brought out very few $\alpha$-L-arabinofuranosidases from different environmental sources (Fortune et al., 2019). Recently, three $\alpha$-L-arabinofuranosidases (AFaseH4, AFaseE3, and AFaseD3) have been reported from the high-temperature compost metagenome (Matsuzawa et al., 2015; Fortune et al., 2019). On characterization, all three display optimum activity at $\mathrm{pH}$ in the acidic range of $\mathrm{pH} 4.0-5.0$ and at $40^{\circ} \mathrm{C}$. However, sequence analysis reveals that $\mathrm{AFaseH} 4-$ and AFaseE3-encoding genes share 100 and $99 \%$ identity with the existing sequences, respectively, while the ORF-encoding AFaseD3 shares 77\% identity with the AFAse of a Paenibacillus taihuensis ORF (Kolinko et al., 2018). Many other metagenomic arabinofuranosidases have shown activity with $\beta$-xylosidases as bifunctional enzymes (Wagschal et al., 2009; Wang et al., 2015; Jordan et al., 2016).

The acetyl xylan esterases (AXEs) (EC 3.1.1.6) cleave the acetyl group from acetyl-xylose moieties and contribute to the complete degradation of the complex xylans. Recently, a few studies have uncovered a handful of AXEs using metagenomic approaches (Adesioye et al., 2018; Brito et al., 2018; Table 2). A metagenomic AXE (Axe1NaM1) was identified by using a hot desert hypolith metagenomic DNA sequence data set (Adesioye et al., 2018). On characterization, it was detected as a mesophilic (Topt. $30^{\circ} \mathrm{C}$ ) and alkaliphilic AXE (pHopt. 8.5). Interestingly, a point mutation (N65S) improved its thermostability as well as catalytic efficiency; the crystal structure of this enzyme has also been solved. In another report, the gut microbiome of a shipworm also identified several AXEs that shared 50$75 \%$ similarity with the available carbohydrate esterases (Brito et al., 2018). Zhu et al. (2016) studied the association and relative abundance of Firmicutes along with lignocellulosedegrading enzymes.

\section{UTILITY OF METAGENOMIC XYLANOLYTIC ENZYMES}

Xylanolytic extremozymes find extensive applications in various industries due to their high performance under extreme conditions (Kumar et al., 2016; Figure 1). Unfortunately, a majority of the metagenomic xylanolytic enzymes are limited to 
biophysical characteristics only (Gong et al., 2013; Kanokratana et al., 2014; Matsuzawa et al., 2015; Ghadikolaei et al., 2019). A handful of metagenome-derived xylan-degrading enzymes have been explored for their applicability in various industrial processes (Jeong et al., 2012; Wang et al., 2015; Berini et al., 2017). The metagenomic xylanase (Mxyl) was successfully employed for bleaching paper pulp samples in the paper industry, and an approximately $24 \%$ reduction in chlorine consumption was achieved (Verma et al., 2013a). Similarly, Ariaeenejad et al. (2019) also report the applicability of camel rumen metagenome-derived xylanase (PersiXyn1) in biobleaching of carton paper pulp. The recombinant enzyme (Mxyl) also finds application in saccharification of agro-residues (wheat bran, corn cob, sugarcane bagasse) for generating XOs of low DP of 2-4 xylose units (Verma et al., 2013b). Such XOs exhibit a prebiotic effect by promoting the growth of probiotic gut microbiota. The xylanase CoXyl43 shows synergistic action with cellulase of $T$. reesei in enhancing its saccharification efficiency on rice straw (Matsuzawa et al., 2015). Sun et al. (2015) achieved an overall 80\% XOs (DP 2-4) from corn cob hemicellulose bioconversion by using metagenomederived Xyn10CD.

The cocktail of $\beta$-xylosidases (RuBG3A/RuBG3B) along with endoxylanases facilitate hemicellulose saccharification efficiently (Bao et al., 2012). Another metagenome-derived cocktail of four thermostable xylanolytic enzymes ( $\beta$-xylosidase and $\beta$-xylosidases $/ \alpha$-arabinofuranosidase) was able to hydrolyze approximately $55 \%$ of the steam-exploded corn cobs at $50^{\circ} \mathrm{C}$ in $48 \mathrm{~h}$ (Wang et al., 2015). Duque et al. (2018) claim that the metagenomic $\beta$-xylosidases are tenfold more efficient than the commercial fungal cocktails of the xylanolytic enzymes. However, Jeong et al. (2012) suggest supplementation of metagenomic xylanases (Xyn10J) with the commercial enzymes to improve their saccharification efficiency. In another report, a compostderived xylanase (XYL40) exhibited higher hydrolysis than the xylanase of TrXyn11A (T. reesei xylanase). Sae-Lee and Boonmee (2014) propose that thermophilic Biof1_09 protein (with dual cellulase and xylanase) can be employed in stone washing and biopolishing industries that require thermostable and acidic extremozymes. Thermophilic xylanase and endoglucanase derived from sugarcane bagasse metagenome enhances the efficiency of a commercial cellulase Celluclast ${ }^{\circledR}$ (Novozymes, Bagsvaerd, Denmark) (Kanokratana et al., 2014). Kim et al. (2018) report the prebiotic effect of xylan hydrolysates on the growth of gut bacterial strains (Bifidobacterium longum and Bifidobacterium lactis). Interestingly, this metagenome-derived thermostable xylanase (KG42) significantly enhances the overall growth of these strains by $95-97 \%$.

A few patents have also described various attributes of metagenome-derived xylan-degrading enzymes. Thermophilic xylanase from a hot spring metagenome has been patented (Patent no: EP2990482 A1) for its application in biofuel production from lignocellulosic biomass (Berini et al., 2017). Two Indian patents (Patent Appl. Nos. 201811041913 and 201711020622) were also filed in 2018 on process devolvement for XO production using metagenome-derived novel xylanases. Radomski et al. (1998) patented a method for retrieving the xylanase gene from soil metagenome (United States Patent US 5849491).

\section{CONCLUSION AND FUTURE PERSPECTIVES}

It has taken more than 15 years to report the first xylanase by Sunna and Bergquist (2003) using a culture-independent approach. Since then, the CAZy database is being enriched by several of the homologue sequences, where the count of GH-10 and GH-11 xylanases dominates the other xylan-degrading proteins. The supremacy of GH-10 xylanases clearly indicates their broad substrate specificity as compared to the GH-11 (true xylanases) members that are quite selective in their substrate range. A majority of the uncovered xylanolytic enzymes are of thermo-acidophilic type; this might be due to their selection from such environments. Better candidates can be recovered by employing a rational approach that includes high-throughput screening of fosmid-derived metagenomic libraries generated from extreme environmental metagenomes on suitable dyeconjugated xylan substrates. In addition, enrichment of cultures under desired physical conditions along with suitable substrates also enhances the success rate multifold to achieve xylanases with the requisite properties. Complementing shotgun sequencing and a PCR-based approach enhances the possibility of retrieving novel xylanolytic extremozymes from the environmental metagenomes.

Undoubtedly, metagenomics has uncovered several novel xylanolytic proteins having unusual properties that were earlier inaccessible. However, it cannot be denied that the recovery of metagenomic xylanolytic enzymes is comparatively higher, and their characterization and industrial applications must be stressed. A handful of reports discuss the feasibility of the retrieved enzymes at the industrial level. We have achieved very little success in utilizing these enzymes. Megazyme ${ }^{2}$ commercialized an endo-1,4- $\beta$-xylanase (from a rumen microorganism) that finds applications in food/feed as well as in paper pulp industries. Similarly, Luminase, a commercial product of $\mathrm{BASF}^{3}$ is also used for biobleaching in paper industries (Berini et al., 2017). We, therefore, emphasize more on characterizing the various available metagenomic xylanases for their applicability and screening for the new candidates.

\section{AUTHOR CONTRIBUTIONS}

Both authors wrote and finalized the manuscript.

\section{ACKNOWLEDGMENTS}

TS is grateful to the University Grant Commission, Government of India, New Delhi and DBT-IUSSTF, New Delhi for providing research grants while writing this review.

\footnotetext{
${ }^{2}$ www.megazyme.com

${ }^{3}$ www.basf.com
} 


\section{REFERENCES}

Adesioye, F. A., Makhalanyane, T. P., Vikram, S., Sewell, B. T., Schubert, W. D., and Cowan, D. A. (2018). Structural characterization and directed evolution of a novel acetyl xylan esterase reveals thermostability determinants of the carbohydrate esterase 7 family. Appl. Environ. Microbiol. 84:e02695-17.

Al-Darkazali, H., Meevootisom, V., Isarangkul, D., and Wiyakrutta, S. (2017). Gene expression and molecular characterization of a xylanase from chicken cecum metagenome. Int. J. Microbiol. 2017:4018398.

Alokika, Singh, D., and Singh, B. (2018). Utility of acidic xylanase of Bacillus subtilis subsp. subtilis JJBS250 in improving the nutritional value of poultry feed. 3 Biotech 8:503.

Alves, K. J., da Silva, M. C. P., and Cotta, S. R. (2020). Mangrove soil as a source for novel xylanase and amylase as determined by cultivation-dependent and cultivation-independent methods. Braz. J. Microbiol. 51, 217-228. doi: 10.1007/ s42770-019-00162-7

Amel, B. D., Nawel, B., Khelifa, B., Mohammed, G., Manon, J., Salima, K. G., et al. (2016). Characterization of a purified thermostable xylanase from Caldicoprobacter algeriensis sp. nov. strain TH7C1T. Carbohydr. Res. 419, 60-68. doi: 10.1016/j.carres.2015.10.013

Anand, A., Kumar, V., and Satyanarayana, T. (2013). Characteristics of thermostable endoxylanase and $\beta$-xylosidase of the extremely thermophilic bacterium Geobacillus thermodenitrificans TSAA1 and its applicability in generating xylooligosaccharides and xylose from agro-residues. Extremophiles 17, 357-366. doi: 10.1007/s00792-013-0524-x

Ariaeenejad, S., Hosseini, E., Maleki, M., Kavousi, K., Moosavi-Movahedi, A. A., and Salekdeh, G. H. (2019). Identification an characterization of a novel thermostable xylanase from camel rumen metagenome. Int. J. Biol. Macromol. 126, 1295-1302. doi: 10.1016/j.ijbiomac.2018.12.041

Badhai, J., Ghosh, T. S., and Das, S. K. (2015). Taxonomic and functional characteristics of microbial communities and their correlation with physicochemical properties of four geothermal springs in Odisha, India. Front. Microbiol. 6:1166. doi: 10.3389/fmicb.2015. 01166

Bailey, M. J., Biely, P., and Poutanen, K. (1992). Inter-laboratory testing of methods for assay of xylanase activity. J. Biotechnol. 23, 257-270. doi: 10.1016/01681656(92)90074-j

Bao, L., Huang, Q., Chang, L., Sun, Q., Zhou, J., and Lu, H. (2012). Cloning and characterization of two $\beta$-glucosidase/xylosidase enzymes from yak rumen metagenome. Appl. Biochem. Biotechnol. 166, 72-86. doi: 10.1007/s12010-0119405-x

Bastien, G., Arnal, G., Bozonnet, S., Laguerre, S., Ferreira, F., Faure, R., et al. (2013). Mining for hemicellulases in the fungus-growing termite Pseudacanthotermes militaris using functional metagenomics. Biotechnol. Biofuels 6:78. doi: 10.1186/ 1754-6834-6-78

Benbelgacem, F. F., Isa, M. N. M., Abdelrahim, M. A. M., Tumian, A., Bellag, O. A., and Parman, A. (2018). Next generation sequencing-data analysis for celluloseand xylan-degrading enzymes from POME metagenome. Sains Malays. 47, 2951-2960. doi: 10.17576/jsm-2018-4712-03

Berini, F., Casciello, C., Marcone, G. L., and Marinelli, F. (2017). Metagenomics: novel enzymes from non-culturable microbes. FEMS Microbiol. Lett. 364:fnx211.

Bouraoui, H., Rebib, H., Ben Aissa, M., Touzel, J. P., O'donohue, M., and Manai, M. (2013). Paenibacillus marinum sp. nov., a thermophilic xylanolytic bacterium isolated from a marine hot spring in Tunisia. J. Basic Microbiol. 53, 877-883. doi: 10.1002/jobm.201200275

Brennan, Y. L., Callen, W. N., Christoffersen, L., Dupree, P., Goubet, F., Healey, S., et al. (2004). Unusual microbial xylanases from insect guts. Appl. Environ. Microbiol. 70, 3609-3617. doi: 10.1128/aem.70.6.3609-3617. 2004

Brito, T. L., Campos, A. B., Bastiaan von Meijenfeldt, F. A., Daniel, J. P., Ribeiro, G. B., and Silva, G. G. Z. (2018). The gill-associated microbiome is the main source of wood plant polysaccharide hydrolases and secondary metabolite gene clusters in the mangrove shipworm Neoteredo reynei. PLoS One 13:e0200437. doi: 10.1371/journal.pone.0200437

Chang, L., Ding, M., Bao, L., Chen, Y., Zhou, J., and Lu, H. (2011). Characterization of a bifunctional xylanase/endoglucanase from yak rumen microorganisms. Appl. Microbiol. Biotechnol. 90, 1933-1942. doi: 10.1007/s00253-011-3182-x
Cheng, F., Sheng, J., Dong, R., Men, Y., Gan, L., and Shen, L. (2012). Novel xylanase from a Holstein cattle rumen metagenomic library and its application in xylooligosaccharide and ferulic acid production from wheat straw. J. Agric. Food Chem. 60, 12516-12524. doi: 10.1021/jf302337w

Cheng, J., Romantsov, T., Engel, K., Doxey, A. C., Rose, D. R., and Neufeld, J. D. (2017). Functional metagenomics reveals novel $\beta$-galactosidases not predictable from gene sequences. PLoS One 12:e0172545. doi: 10.1371/journal. pone. 0172545

DeCastro, M. E., Rodriguez-Belmonte, E., and Gonzalez-Siso, M. I. (2016). Metagenomics of thermophiles with a focus on discovery of novel thermozymes. Front. Microbiol. 7:1521. doi: 10.3389/fmicb.2016.01521

Duque, E., Daddaoua, A., Cordero, B. F., Udaondo, Z., Molina-Santiago, C., Roca, A., et al. (2018). Ruminal metagenomic libraries as a source of relevant hemicellulolytic enzymes for biofuel production. Microb. Biotechnol. 11, 781787. doi: 10.1111/1751-7915.13269

Ellila, S., Bromann, P., and Nyyssonen, M. (2019). Cloning of novel bacterial xylanases from lignocellulose-enriched compost metagenomic libraries. $A M B$ Express 9:124.

Fortune, B., Mhlongo, S., Van Zyl, L. J., Huddy, R., Smart, M., and Trindade, M. (2019). Characterisation of three novel $\alpha$-L-arabinofuranosidases from a compost metagenome. BMC Biotechnol. 19:22. doi: 10.1186/s12896-019-05101

Fredriksen, L., Stokke, R., Jensen, M. S., Westereng, B., Jameson, J. K., Steen, I., et al. (2019). Discovery of a thermostable GH10 xylanase with broad substrate specificity from the Arctic Mid-Ocean Ridge vent system. Appl. Environ. Microbiol. 85:e02970-18.

Ghadikolaei, K. K., Sangachini, E. D., Vahdatirad, V., Noghabi, K. A., and Zahiri, H. S. (2019). An extreme halophilic xylanase from camel rumen metagenome with elevated catalytic activity in high salt concentrations. AMB Express 9:86.

Gong, X., Gruniniger, R. J., Forster, R. J., Teather, R. M., and McAllister, T. A. (2013). Biochemical analysis of a highly specific, pH stable xylanase gene identified from a bovine rumen-derived metagenomic library. Appl. Microbiol. Biotechnol. 97, 2423-2431. doi: 10.1007/s00253-012-4088-y

Gruppen, H., Hamer, R. J., and Voragen, A. G. J. (1992). Water unextractable cell wall material from wheat flour. 2. Fractionation of alkali extracted polymers and comparison with water extractable arabinoxylans. J. Cereal Sci. 16, 53-67. doi: 10.1016/s0733-5210(09)80079-9

Guo, B., Chen, X., Sun, C., Zhou, B., and Zhang, Y. (2009). Gene cloning, expression and characterization of a new cold-active and salt tolerant endo$\beta$-1, 4-xylanase from marine Glaciecola mesophila KMM 241. Appl. Microbiol. Biotechnol. 84, 1107-1115. doi: 10.1007/s00253-009-2056-y

Haki, G. D., and Rakshit, S. K. (2003). Developments in industrially important thermostable enzymes: a review. Biores. Technol. 89, 17-34. doi: 10.1016/s09608524(03)00033-6

Haro-Moreno, J. M., Lopez-Perez, L., de la Torre, J. R., Picazo, A., Camacho, A., and Rodriguez-Valera, F. (2018). Fine metagenomic profile of the Mediterranean stratified and mixed water columns revealed by assembly and recruitment. Microbiome 6:128.

Harris, A. D., and Ramalingam, C. (2010). Xylanases and its application in food industry: a review. J. Exp. Sci. 1, 1-11.

Helianti, I. (2007). Direct cloning of a xylanase gene from Pawan-riau hot spring. HAYATI J. Biosci. 14, 54-58. doi: 10.4308/hjb.14.2.54

Holck, J., Djajadi, D. T., Brask, J., Pilgaard, B., Krogh, K. B. R. M., Meyer, A. S., et al. (2019). Novel xylanolytic triple domain enzyme targeted at feruloylated arabinoxylan degradation. Enzyme Microb. Technol. 129:109353. doi: 10.1016/ j.enzmictec.2019.05.010

Hu, Y., Zhang, G., Li, A., Chen, J., and Ma, L. (2008). Cloning and enzymatic characterization of a xylanase gene from a soil-derived metagenomic library with an efficient approach. Appl. Microbiol. Biotechnol. 80, 823-830.

Jain, I., Kumar, V., and Satyanarayana, T. (2014). Applicability of recombinant $\beta$-xylosidase from the extremely thermophilic bacterium Geobacillus thermodenitrificans in synthesizing alkylxylosides. Biores. Technol. 170, 462-469. doi: 10.1016/j.biortech.2014.07.113

Jain, I., Kumar, V., and Satyanarayana, T. (2015). Xylooligosaccharides: an economical prebiotic from agroresidues and their health benefits. Indian J. Exp. Biol. 53, 131-142.

Jeong, Y. S., Na, H. B., Kim, S. K., Kim, Y. H., Kwon, E. J., Kim, J., et al. (2012). Characterization of xyn10J, a novel family 10 xylanase from a compost 
metagenomic library. Appl. Biochem. Biotechnol. 166, 1328-1339. doi: 10.1007/ s12010-011-9520-8

Jordan, D. B., Braker, J. D., and Wagschal, K. (2016). Isolation and divalent metal activation of a $\beta$-xylosidase, RUM630-BX. Enzyme Microb. Technol. 82, 158-163. doi: 10.1016/j.enzmictec.2015.10.001

Jordan, D. B., Stoller, R., Kibblewhite, R. E., Chan, V. J., Lee, C. C., and Wagschal, K. (2018). Absence or presence of metal ion activation in two structurally similar GH43 $\beta$-xylosidases. Enzy. Microb. Technol. 114, 29-32. doi: 10.1016/ j.enzmictec.2018.03.007

Kanokratana, P., Eurwilaichitr, L., Pootanakit, K., and Champreda, V. (2014). Identification of glycosyl hydrolases from a metagenomic library of microflora in sugarcane bagasse collection site and their cooperative action on cellulose degradation. J. Biosci. Bioeng. 119, 384-391. doi: 10.1016/j.jbiosc.2014.09.010

Kaushal, G., Kumar, J., Sangwan, R. S., and Singh, S. P. (2018). Metagenomic analysis of geothermal water reservoir sites exploring carbohydrate related thermozymes. Int. J. Biol. Macromol. 119, 882-895. doi: 10.1016/j.ijbiomac. 2018.07.196

Khandeparker, R., and Numan, M. H. (2008). Bi-functional xylanases and their potential use in biotechnology. J. Ind. Microbiol. Biotechnol. 35, 635-644. doi: 10.1007/s10295-008-0342-9

Kim, H. B., Leeb, K. T., Kim, M. J., Lee, J. S., and Kim, K. S. (2018). Identification and characterization of a novel KG42 xylanase (GH10 family) isolated from the black goat rumen-derived metagenomic library. Carbohydr. Res. 469, 1-9. doi: 10.1016/j.carres.2018.08.010

Knapik, K., Becerra, M., and Gonzqlez-Siso, M. (2019). Microbial diversity analysis and screening for novel xylanase enzymes from the sediment of the Lobios Hot Spring in Spain. Sci. Rep. 9:11195.

Kolinko, S., Wu, Y. W., Tachea, F., Denzel, E., Hiras, J., Gabriel, R., et al. (2018). A bacterial pioneer produces cellulase complexes that persist through community succession. Nat. Microbiol. 3, 99-107. doi: 10.1038/s41564-017-0052-z

Kormelink, F. J. M., and Voragen, A. G. J. (1993). Degradation of different [(glucurono) arabino] xylans by a combination of purified xylan-degrading enzymes. Appl. Microbiol. Biotechnol. 38, 688-695.

Kumar, J., Sharma, N., Kaushal, G., Samurailatpam, S., Sahoo, D., Rai, A. K., et al. (2019). Metagenomic insights into the taxonomic and functional features of Kinema, a traditional fermented soybean product of Sikkim Himalaya. Front. Microbiol. 10:1744. doi: 10.3389/fmicb.2019.01744

Kumar, V., Marin-Navarro, J., and Shukla, P. (2016). Thermostable microbial xylanases for pulp and paper industries: trends, applications and further perspectives. World J. Microbiol. Biotechnol. 32, 1-10.

Kumar, V., and Satyanarayana, T. (2014). Production of endoxylanase with enhanced thermostability by a novel polyextremophilic Bacillus halodurans TSEV1 and its applicability in waste paper deinking. Process Biochem. 49, 386-394. doi: 10.1016/j.procbio.2013.12.005

Kumar, V., Syal, P., and Satyanarayana, T. (2013a). Highly thermo-halo-alkalistable $\beta$-1,4-endoxylanase from a novel polyextremophilic strain of Bacillus halodurans. Bioprocess Biosyst. Eng. 36, 555-565. doi: 10.1007/s00449-0120811-4

Kumar, V., Verma, D., and Satyanarayana, T. (2013b). Extremophilic bacterial xylanases: production, characteristics and applications. Curr. Biotechnol. 2, 380-399. doi: 10.2174/18722083113076660027

Kuramochi, K., Uchimura, K., and Kurata, A. (2016). A high-molecularweight, alkaline, and thermostable $\beta$-1,4-xylanase of a subseafloor Microcella alkaliphila. Extremophiles 20, 471-478. doi: 10.1007/s00792-016-0837-7

Kwon, E. J., Jeong, Y. S., Kim, Y. H., Kim, S. K., Na, H. B., Kim, J., et al. (2010). Construction of a metagenomic library from compost and screening of cellulase- and xylanase-positive clones. J. Appl. Biol. Chem. 53, 702-708. doi: $10.3839 /$ jksabc. 2010.106

Lee, C. C., Kibblewhite-Accinelli, R. E., Wagschal, K., Robertson, G. H., and Wong, D. W. S. (2006). Cloning and characterization of a cold-active xylanase enzyme from an environmental DNA library. Extremophiles 10, 295-300. doi: 10.1007/ s00792-005-0499-3

Lee, K. T., Toushik, S. H., Baek, J. Y., Kim, J. E., Lee, J. S., and Kim, K. S. (2018). Metagenomic mining and functional characterization of a novel KG51 bifunctional cellulase/hemicellulase from black goat rumen. J. Agric. Food Chem. 66, 9034-9041. doi: 10.1021/acs.jafc.8b01449

Leth, M. L., Ejby, M., Workman, C., Ewald, D. A., Pedersen, S. S., Sternberg, C., et al. (2018). Differential bacterial capture and transport preferences facilitate co-growth on dietary xylan in the human gut. Nat. Microbiol. 3, 570-580. doi: 10.1038/s41564-018-0132-8

Li, R., Kibblewhite, R., Orts, W. J., and Lee, C. C. (2009). Molecular cloning and characterization of multidomain xylanase from manure library. World J. Microbiol. Biotechnol. 25, 2071-2078. doi: 10.1007/s11274-009-0111-6

Li, Z., Li, X., Liu, T., Chen, S., Liu, H., Wang, H., et al. (2019). The critical roles of exposed surface residues for the thermostability and halotolerance of a novel GH11 xylanase from the metagenomic library of a saline-alkaline soil. Int. J. Biol. Macromol. 133, 316-323. doi: 10.1016/j.ijbiomac.2019.04.090

Liu, C., Zou, G., Yan, X., and Zhou, X. (2018). Screening of multimeric $\beta$-xylosidases from the gut microbiome of a higher termite, Globitermes brachycerastes. Int. J. Biol. Sci. 14, 608-615. doi: 10.7150/ijbs.22763

Liu, J. R., Yu, B., Lin, S. H., Cheng, K. J., and Chen, Y. C. (2005). Direct cloning of a xylanase gene from the mixed genomic DNA of rumen fungi and its expression in intestinal Lactobacillus reuteri. FEMS Microbiol. Lett. 251, 233-241. doi: 10.1016/j.femsle.2005.08.008

Liu, N., Li, H., and Chevrette, M. G. (2019). Functional metagenomics reveals abundant polysaccharide-degrading gene clusters and cellobiose utilization pathways within gut microbiota of a wood-feeding higher termite. ISME J. 13, 104-117. doi: 10.1038/s41396-018-0255-1

Lorenz, P., and Eck, J. (2005). Metagenomics and industrial applications. Nat. Rev. Microbiol. 3, 510-516. doi: 10.1038/nrmicro1161

Mamo, G., Hatti-Kaul, R., and Mattiasson, B. (2006). A thermostable alkaline active endo- $\beta$-1-4-xylanase from Bacillus halodurans S7: purification and characterization. Enzyme Microb. Technol. 39, 1492-1498. doi: 10.1016/j. enzmictec.2006.03.040

Maruthamuthu, M., Jimenez, D. J., and van Elsas, J. D. (2017). Characterization of a furan aldehyde-tolerant $\beta$-xylosidase $/ \alpha$-arabinosidase obtained through a synthetic metagenomics approach. J. Appl. Microbiol. 123, 145-158. doi: 10.1111/jam.13484

Matsuzawa, T., Kaneko, S., and Yaoi, K. (2015). Screening, identification and characterization of a GH43 family $\beta$-xylosidase/ $\alpha$-arabinosidase useful for biomass saccharification from a compost microbial metagenome. Appl. Microbiol. Biotechnol. 99, 8943-8954. doi: 10.1007/s00253-0156647-5

Matsuzawa, T., Kimura, N., and Suenaga, H. (2016). Screening, identification, and characterization of $\alpha$-xylosidase from a soil metagenome. J. Biosci. Bioeng. 122, 393-399. doi: 10.1016/j.jbiosc.2016.03.012

Mo, X. C., Chen, C. L., Pang, H., Feng, Y., and Feng, J. X. (2010). Identification and characterization of a novel xylanase derived from a rice straw degrading enrichment culture. Appl. Microbiol. Biotechnol. 87, 2137-2146. doi: 10.1007/ s00253-010-2712-2

Mori, T., Kamei, I., Hirai, H., and Kondo, R. (2014). Identification of novel glycosyl hydrolases with cellulolytic activity against crystalline cellulose from metagenomic libraries constructed from bacterial enrichment cultures. Springerplus 3:365. doi: 10.1186/2193-1801-3-365

Ngara, T. R., and Zhang, H. (2018). Recent advances in function-based metagenomic screening. Genomics Proteomics Bioinformatics. 16, 405-415. doi: 10.1016/j.gpb.2018.01.002

Palackal, N., Lyon, C., Zaidi, S., Luginbuhl, P., Dupree, P., Goubet, F., et al. (2007). A multifunctional hybrid glycosyl hydrolase discovered in an uncultured microbial consortium from ruminant gut. Appl. Microbiol. Biotechnol. 74, 113-124. doi: 10.1007/s00253-006-0645-6

Qian, C., Liu, N., Yan, X., Wang, Q., Zhou, Z., and Wang, Q. (2015). Engineering a high-performance, metagenomic-derived novel xylanase with improved soluble protein yield and thermostability. Enzyme Microb. Technol. 70, 35-41. doi: 10.1016/j.enzmictec.2014.11.005

Radomski, C. C. A., Seow, K. T., Warren, R. A. J., and Yap, W. H. (1998). Method for isolating xylanase gene sequences from soil DNA, compositions useful in such method and compositions obtained thereby. U.S. Patent No 5,849,491. Washington, DC: U.S. Patent and Trademark Office.

Rashamuse, K., Sanyika Tendai, W., Mathiba, K., Ngcobo, T., Mtimka, S., and Brady, D. (2016). Metagenomic mining of glycoside hydrolases from the hindgut bacterial symbionts of a termite (Trinervitermes trinervoides) and the characterization of a multimodular $\beta$-1,4-xylanase (GH11). Biotechnol. Appl. Biochem. 64, 174-186. doi: 10.1002/bab.1480

Rennie, E. A., and Scheller, H. V. (2014). Xylan biosynthesis. Curr. Opin. Biotechnol. 26, 100-107. doi: 10.1016/j.copbio.2013.11.013 
Rohman, A., Dijkstra, B. W., and Puspaningsih, N. N. T. (2019). $\beta$-Xylosidases: structural diversity, catalytic mechanism, and inhibition by monosaccharides. Int. J. Mol. Sci. 20:5524. doi: 10.3390/ijms20225524

Sae-Lee, R., and Boonmee, A. (2014). Newly derived GH43 gene from compost metagenome showing dual xylanase and cellulase activities. Folia Microbiol. 59, 409-417. doi: 10.1007/s12223-014-0313-7

Sato, M., Suda, M., Okuma, J., Kato, T., Hirose, Y., Nishimura, A., et al. (2017). Isolation of highly thermostable $\beta$-xylosidases from a hot spring soil microbial community using a metagenomic approach. DNA Res. 24, 649-656. doi: 10. 1093/dnares/dsx032

Selvarajan, E., and Veena, R. (2017). Recent advances and future perspectives of thermostable xylanase. Biomed. Pharmacol. J. 10, 261-279. doi: 10.13005/bpj/ 1106

Shahraki, M. F., Farhadyar, K., Kavousi, K., Azarabad, M. A., Boroomand, A., Ariaeenejad, S., et al. (2019). TAXyl: an in-silico method for predicting the thermal activity for xylanases from GH10 and GH11 families. bioRxiv [Preprint] doi: $10.1101 / 826040$

Shallom, D., and Shoham, Y. (2003). Microbial hemicellulases. Curr. Opin. Microbiol. 6, 219-228. doi: 10.1016/s1369-5274(03)00056-0

Shao, W., and Wiegel, J. (1992). Purification and characterization of a thermostable b-xylosidase from Thermoanaerobacter ethanolicus. J. Bacteriol. 174, 58485853. doi: $10.1128 / \mathrm{jb} .174 .18 .5848-5853.1992$

Sharma, S., Adhikari, S., and Satyanarayana, T. (2007). Alkali-thermostable and cellulase free xylanase production by an extreme thermophile Geobacillus thermoleovorans. World J. Microbiol. Biotechnol. 23, 483-490. doi: 10.1007/ s11274-006-9250-1

Sharpton, T. J. (2014). An introduction to the analysis of shotgun metagenomic data. Front. Plant Sci. 5:209. doi: 10.3389/fpls.2014.00209

Sheng, P., Li, Y., Marshall, S. D. G., and Zhang, H. (2015). High genetic diversity of microbial cellulase and hemicellulase genes in the hindgut of Holotrichia parallela larvae. Int. J. Mol. Sci. 16, 16545-16559. doi: 10.3390/ijms1607 16545

Shi, H., Zhang, Y., Li, X., Huang, Y., Wang, L., Wang, Y., et al. (2013). A novel highly thermostable xylanase stimulated by $\mathrm{Ca} 2+$ from Thermotoga thermarum: cloning, expression and characterization. Biotechnol. Biofuels 6:26. doi: 10 . 1186/1754-6834-6-26

Shi, H., Zhang, Y., Zhang, H., Huang, Y., Li, X., and Wang, F. (2014). Cloning, over-expression and characterization of a thermo- tolerant xylanase from Thermotoga thermarum. Biotechnol. Lett. 36, 587-593. doi: 10.1007/s10529013-1392-2

Shi, W., Ding, S. Y., and Yuan, J. S. (2011). Comparison of insect gut cellulase and xylanase activity across different insect species with distinct food sources. Bioenergy Res. 4, 1-10. doi: 10.1007/s12155-010-9096-0

Shi, W., Xie, S., Chen, X., Sun, S., Zhou, X., Liu, L., et al. (2013). Comparative genomic analysis of the endosymbionts of herbivorous insects reveals eco-environmental adaptations: biotechnology applications. PLoS Genet. 9:e1003131. doi: 10.1371/journal.pgen.1003131

Simpson, H. D., Haufler, U. R., and Daniel, R. M. (1991). An extremely thermostable xylanase from the thermophilic eubacterium Thermotoga. Biochem. J. 277(Pt 2), 413-417. doi: 10.1042/bj2770413

Singh, K. M., Reddy, B., and Patel, D. (2014). High potential source for biomass degradation enzyme discovery and environmental aspects revealed through metagenomics of Indian buffalo rumen. Biomed Res. Int. 2014:26 7189.

Sriprang, R., Asano, K., Gobsuk, J., Tanapongpipat, S., Champreda, V., and Eurwilaichitr, L. (2006). Improvement of thermostability of fungal xylanase by using site directed mutagenesis. J. Biotechnol. 12, 454-462. doi: 10.1016/j. jbiotec.2006.04.031

Sun, M., Zheng, H., and Meng, L. (2015). Direct cloning, expression of a thermostable xylanase gene from the metagenomic DNA of cow dung compost and enzymatic production of xylooligosaccharides from corncob. Biotechnol. Lett. 37, 1877-1886. doi: 10.1007/s10529-015-1857-6

Sunna, A., and Antranikian, G. (1997). Xylanolytic enzymes from fungi and bacteria. Crit. Rev. Biotechnol. 17, 39-67. doi: 10.3109/07388559709146606

Sunna, A., and Bergquist, P. L. (2003). A gene encoding a novel extremely thermostable 1,4- $\beta$-xylanase isolated directly from an environmental DNA sample. Extremophiles 7, 63-70. doi: 10.1007/s00792-002-0296-1
Thidarat, N., Thongaram, T., Uengwetwanit, T., Pongpattanakitshote, S., and Eurwilaichitr, L. (2012). Metagenomic analysis of novel lignocellulosedegrading enzymes from higher termite guts inhabiting microbes. J. Microbiol. Biotechnol. 22, 462-469. doi: 10.4014/jmb.1108.08037

Thornbury, M., Sicheri, J., Slaine, P., Getz, L. J., Finlayson-Trick, E., and Cook, J. (2019). Characterization of novel lignocellulose-degrading enzymes from the porcupine microbiome using synthetic metagenomics. PLoS One 14:e0209221. doi: 10.1371/journal.pone.0209221

Turunen, O., Vuorio, M., Fenel, F., and Leisola, M. (2002). Engineering of multiple arginines into the Ser/Thr surface of Trichoderma reesei endo-1,4-beta-xylanase II increases the thermotolerance and shifts the $\mathrm{pH}$ optimum towards alkaline pH. Protein Eng. 15, 141-145. doi: 10.1093/protein/15.2.141

Uhl, A. M., and Daniel, R. M. (1999). The first description of an archaeal hemicellulase: the xylanase from Thermococcus zilligii strain AN1. Extremophiles 3, 263-267. doi: 10.1007/s007920050126

Verma, D., Anand, A., and Satyanarayana, T. (2013a). Thermostable and alkalistable endoxylanase of the extremely thermophilic bacterium Geobacillus thermodenitrificans TSAA1: cloning, expression, characteristics and its applicability in generating xylooligosaccharides and fermentable sugars. Appl. Biochem. Biotechnol. 170, 119-130. doi: 10.1007/s12010-0130174-6

Verma, D., Kawarabayasi, Y., Miyazaki, K., and Satyanarayana, T. (2013b). Cloning, expression and characteristics of a novel alkalistable and thermostable xylanase encoding gene (Mxyl) retrieved from compost-soil metagenome. PLoS One 8:e52459. doi: 10.1371/journal.pone.0052459

Verma, D., Kumar, R., and Satyanarayana, T. (2019). "Diversity in xylan-degrading prokaryotes and xylanolytic enzymes and their bioprospects," in Microbial Diversity in Ecosystem Sustainability and Biotechnological Applications, eds T. Satyanarayana, S. K. Das, and B. N. Johri (London: Springer Nature), 325-373. doi: 10.1007/978-981-13-8487-5_14

Verma, D., and Satyanarayana, T. (2012). Cloning, expression and applicability of thermo-alkali-stable xylanase of Geobacillus thermoleovorans in generating xylooligosaccharides from agro-residues. Biores. Technol. 107, 333-338. doi: 10.1016/j.biortech.2011.12.055

Verma, D., and Satynarayana, T. (2011). An improved protocol for DNA extraction from alkaline soil and sediment samples for constructing metagenomic libraries. Appl. Biochem. Biotechnol. 165, 454-464. doi: 10.1007/s12010-0119264-5

Victorica, M. R., Soria, M. A., Batista-Garcia, R. A., Ceja-Navarro, J. A., and Vikram, S. (2020). Neotropical termite microbiomes as sources of novel plant cell wall degrading enzymes. Sci. Rep. 10:3864.

Wagschal, K., Heng, C., Lee, C. C., and Wong, D. W. (2009). Biochemical characterization of a novel dual-function $\alpha$-arabinofuranosidase/ $\beta$-xylosidase isolated from a compost starter mixture. Appl. Microbiol. Biotechnol. 81, 855863. doi: $10.1007 / \mathrm{s} 00253-008-1662-4$

Wang, C., Dong, D., and Wang, H. (2016). Metagenomic analysis of microbial consortia enriched from compost: new insights into the role of Actinobacteria in lignocellulose decomposition. Biotechnol. Biofuels 9:22.

Wang, G., Wang, Y., Yang, P., Luo, H., Huang, H., Shi, P., et al. (2010). Molecular detection and diversity of xylanase genes in alpine tundra soil. Appl. Microbiol. Biotechnol. 87, 1383-1393. doi: 10.1007/s00253-0102564-9

Wang, Q., Luo, Y., He, B., Jiang, L. S., Liu, J. X., and Wang, J. K. (2015). Characterization of a novel xylanase gene from rumen content of $\mathrm{Hu}$ sheep. Appl. Biochem. Biotechnol. 177, 1424-1436. doi: 10.1007/s12010-0151823-8

Wang, W., Hu, H., and Zijlstra, R. T. (2019). Metagenomic reconstructions of gut microbial metabolism in weanling pigs. Microbiome 7:48.

Wilkens, C., Andersen, S., Dumon, C., Berrin, J. G., and Svensson, B. (2017). GH62 arabinofuranosidases: structure, function and applications. Biotechnol. Adv. 35, 792-804. doi: 10.1016/j.biotechadv.2017.06.005

Wiseschart, A., Mhuantong, W., and Tangphatsornruang, S. (2019). Shotgun metagenomic sequencing from Manao-Pee cave, Thailand, reveals insight into the microbial community structure and its metabolic potential. BMC Microbiol. 19:144. doi: 10.1186/s12866-019-1521-8

Yamada, K., Terahara, T., Kurata, S., Yokomaku, T., Tsuneda, S., and Harayama, S. (2008). Retrieval of entire genes from environmental DNA by inverse PCR with 
pre-amplification of target genes using primers containing locked nucleic acids. Environ. Microbiol. 10, 978-987. doi: 10.1111/j.1462-2920.2007.01518.x

Yan, R., Vuong, T. V., Wang, W., and Master, E. R. (2017). Action of a GH115 $\alpha$-glucuronidase from Amphibacillus xylanus at alkaline condition promotes release of 4-O methylglucopyranosyluronic acid from glucuronoxylan and arabinoglucuronoxylan. Enzyme Microb. Technol. 104, 22-28. doi: 10.1016/j. enzmictec.2017.05.004

Zhang, M., Chekan, J. R., Dodd, D., Hong, P. Y., Radlinski, L., Revindran, V., et al. (2014). Xylan utilization in human gut commensal bacteria is orchestrated by unique modular organization of polysaccharide-degrading enzymes. Proc. Natl. Acad. Sci. U.S.A. 111, E3708-E3717.

Zhao, S., Bu, D., Wang, J., Liu, K., Zhu, Y., Dong, Z., et al. (2010). Novel glycoside hydrolases from a metagenome library of the rumen of Chinese holstein dairy cows. Appl. Environ. Microbiol. 76, 6701-6705. doi: 10.1128/aem.00361-10

Zhou, J., Bao, L., Chang, L., Zhou, Y., and Lu, H. (2012). Biochemical and kinetic characterization of GH43 $\beta$-D-xylosidase/ $\alpha$-L-arabinofuranosidase and GH30 $\alpha$-L-arabinofuranosidase/ $\beta$-D -xylosidase from rumen metagenome. J. Ind. Microbiol. Biotechnol. 39, 143-152. doi: 10.1007/s10295-011-1009-5
Zhou, L., Bao, L., Chang, L., Liu, Z., You, C., and Lu, H. (2011). Beta-xylosidase activity of a $\mathrm{GH} 3$ glucosidase/xylosidase from yak rumen metagenome promotes the enzymatic degradation of hemicellulosic xylans. Lett. Appl. Microbiol. 54, 79-87. doi: 10.1111/j.1472-765x.2011.03175.x

Zhu, N., Yang, J., and Ji, L. (2016). Metagenomic and metaproteomic analyses of a corn stover-adapted microbial consortium EMSD5 reveal its taxonomic and enzymatic basis for degrading lignocellulose. Biotechnol. Biofuels 9:243.

Conflict of Interest: The authors declare that the research was conducted in the absence of any commercial or financial relationships that could be construed as a potential conflict of interest.

Copyright (c) 2020 Verma and Satyanarayana. This is an open-access article distributed under the terms of the Creative Commons Attribution License (CC BY). The use, distribution or reproduction in other forums is permitted, provided the original author(s) and the copyright owner(s) are credited and that the original publication in this journal is cited, in accordance with accepted academic practice. No use, distribution or reproduction is permitted which does not comply with these terms. 